\title{
Molecular transformations of phenolic SOA during photochemical aging in the aqueous phase: competition among oligomerization, functionalization, and fragmentation
}

\author{
Lu Yu ${ }^{1}$, Jeremy Smith ${ }^{2}$, Alexander Laskin ${ }^{3}$, Katheryn M. George ${ }^{4}$, Cort Anastasio ${ }^{2}$, Julia Laskin ${ }^{5}$, Ann M. Dillner ${ }^{4}$, \\ and Qi Zhang ${ }^{1}$ \\ ${ }^{1}$ Department of Environmental Toxicology, University of California, 1 Shields Ave., Davis, CA 95616, USA \\ ${ }^{2}$ Department of Land, Air and Water Resources, University of California, 1 Shields Ave., Davis, CA 95616, USA \\ ${ }^{3}$ Environmental Molecular Sciences Laboratory, Pacific Northwest National Laboratory, Richland, WA 99352, USA \\ ${ }^{4}$ Crocker Nuclear Laboratory, University of California, 1 Shields Ave., Davis, CA 95616, USA \\ ${ }^{5}$ Physical Sciences Division, Pacific Northwest National Laboratory, Richland, WA 99352, USA
}

Correspondence to: Qi Zhang (dkwzhang@ucdavis.edu)

Received: 7 October 2015 - Published in Atmos. Chem. Phys. Discuss.: 30 October 2015

Revised: 23 March 2016 - Accepted: 4 April 2016 - Published: 13 April 2016

\begin{abstract}
Organic aerosol is formed and transformed in atmospheric aqueous phases (e.g., cloud and fog droplets and deliquesced airborne particles containing small amounts of water) through a multitude of chemical reactions. Understanding these reactions is important for a predictive understanding of atmospheric aging of aerosols and their impacts on climate, air quality, and human health. In this study, we investigate the chemical evolution of aqueous secondary organic aerosol (aqSOA) formed during reactions of phenolic compounds with two oxidants - the triplet excited state of an aromatic carbonyl $\left({ }^{3} \mathrm{C}^{*}\right)$ and hydroxyl radical $\left({ }^{\bullet} \mathrm{OH}\right)$. Changes in the molecular composition of aqSOA as a function of aging time are characterized using an offline nanospray desorption electrospray ionization mass spectrometer (nano-DESI MS) whereas the real-time evolution of SOA mass, elemental ratios, and average carbon oxidation state $\left(\mathrm{OS}_{\mathrm{C}}\right)$ are monitored using an online aerosol mass spectrometer (AMS). Our results indicate that oligomerization is an important aqueous reaction pathway for phenols, especially during the initial stage of photooxidation equivalent to $\sim 2 \mathrm{~h}$ irradiation under midday winter solstice sunlight in Northern California. At later reaction times functionalization (i.e., adding polar oxygenated functional groups to the molecule) and fragmentation (i.e., breaking of covalent bonds) become more important processes, forming a large variety of functionalized aromatic and open-ring products
\end{abstract}

with higher $\mathrm{OS}_{C}$ values. Fragmentation reactions eventually dominate the photochemical evolution of phenolic aqSOA, forming a large number of highly oxygenated ring-opening molecules with carbon numbers $\left(n_{\mathrm{C}}\right)$ below 6 . The average $n_{\mathrm{C}}$ of phenolic aqSOA decreases while average $\mathrm{OS}_{\mathrm{C}}$ increases over the course of photochemical aging. In addition, the saturation vapor pressures $\left(C^{*}\right)$ of dozens of the most abundant phenolic aqSOA molecules are estimated. A wide range of $C^{*}$ values is observed, varying from $<10^{-20} \mu \mathrm{g} \mathrm{m}{ }^{-3}$ for functionalized phenolic oligomers to $>10 \mu \mathrm{g} \mathrm{m}^{-3}$ for small open-ring species. The detection of abundant extremely low-volatile organic compounds (ELVOC) indicates that aqueous reactions of phenolic compounds are likely an important source of ELVOC in the atmosphere.

\section{Introduction}

Secondary organic aerosol (SOA), which accounts for a major fraction of fine particle mass in the atmosphere (Jimenez et al., 2009; Zhang et al., 2007), is formed and transformed through a multitude of chemical and physical processes (Ervens et al., 2011; Hallquist et al., 2009; Jimenez et al., 2009; Ervens, 2015). The chemical transformation of SOA can be described by three competing mechanisms - functionalization, fragmentation, and oligomerization (Kroll and Seinfeld, 
2008; Kroll et al., 2009). Functionalization adds polar oxygenated functional groups to a molecule and generally decreases its volatility; fragmentation breaks covalent bonds in a molecule and tends to increase its volatility; and oligomerization combines two or more molecules through covalent bonds, producing a larger molecule with substantially lower volatility. While these pathways occur in parallel, oxidative fragmentation usually becomes more important over the course of atmospheric aging, leading to the formation of increasingly more oxidized organic aerosol as well as volatile molecules that are lost from the particles. Analyses of ambient aerosol data sets acquired worldwide with aerosol mass spectrometers (AMSs) have indeed shown that less oxidized, semi-volatile oxygenated organic aerosol (SV-OOA) generally evolves into highly oxidized, low-volatility oxygenated organic aerosol (LV-OOA) during atmospheric aging ( $\mathrm{Ng}$ et al., 2010; Morgan et al., 2010).

The aging of organic aerosol has been investigated in a number of laboratory and field studies (e.g., Kroll and Seinfeld, 2008; Jimenez et al., 2009; Renard et al., 2015; Morgan et al., 2010). While most of the studies have so far focused on gas-phase photochemical processes, aqueous reactions are also ubiquitous and can influence aerosol composition and properties significantly (e.g., Blando and Turpin, 2000; Lim et al., 2010; Ervens et al., 2011; Hennigan et al., 2012; Altieri et al., 2012; Zhang and Anastasio, 2003; Lee et al., 2012; Ge et al., 2012; Ervens, 2015). Understanding the formation and transformation of SOA through aqueous reactions is therefore important for elucidating the atmospheric evolution of particles and modeling their impacts on climate and human health.

In this work we examine the aqueous reactions of phenols, which are a family of lignin-derived compounds emitted in large quantities from biomass burning (Hawthorne et al., 1989; Schauer et al., 2001). Oxidation of aromatic hydrocarbons in anthropogenic emissions can also lead to the formation of phenols (Graber and Rudich, 2006). Studies have shown that volatile phenols and benzenediols are rapidly oxidized by hydroxyl radical $\left(\bullet^{\bullet} \mathrm{OH}\right)$, nitrate radical $\left(\mathrm{NO}_{3}^{\bullet}\right)$, and excited triplet states $\left({ }^{3} \mathrm{C}^{*}\right)$ of aromatic carbonyls in the aqueous phase (Herrmann, 2003; Anastasio et al., 1997), forming aqSOA (i.e., low-volatility species formed via aqueous reactions of volatile precursors) with high mass yields (Smith et al., 2014, 2015; Sun et al., 2010). The lifetimes of phenols with respect to ${ }^{3} \mathrm{C}^{*}$ and ${ }^{\circ} \mathrm{OH}$ reactions in atmospheric fog and cloud water are on the order of minutes to hours during daytime (Smith et al., 2014), which is of the same order as the gas-phase oxidation of phenols (i.e., hours) (Feigenbrugel et al., 2004). Furthermore, recent studies in our group have shown that the aqSOA of phenols are highly oxidized, with average atomic oxygen-to-carbon $(\mathrm{O} / \mathrm{C})$ ratios of $\sim 1$ and are comprised of a large number of water-soluble molecules with polar functional groups including carbonyl, carboxyl, and hydroxyl groups (Sun et al., 2010; Yu et al., 2014;
George et al., 2015). This is an indication that phenolic aqSOA can influence the hygroscopicity of ambient particles and thus their cloud formation potential. In addition, phenolic aqSOA shows enhanced light absorption in the UV-visible region compared to their precursors (Chang and Thompson, 2010; Yu et al., 2014), which suggests that they are likely an important component of brown carbon in the atmosphere (Laskin et al., 2015; Andreae and Gelencsér, 2006), especially in regions influenced by biomass burning emissions. Despite this, little is known about how the chemical composition and physical properties of phenolic aqSOA evolve as a function of photochemical age in the atmosphere.

We investigate the chemical evolution of aqSOA formed from the three basic structures of phenols (phenol, guaiacol, and syringol) during reactions with two major aqueous-phase oxidants $-{ }^{3} \mathrm{C}^{*}$ and ${ }^{\bullet} \mathrm{OH}$. Note that we use the generic term "phenol" in this paper to refer to all phenolic compounds and the abbreviations $\mathrm{PhOH}$, GUA, and SYR to specifically refer to phenol $\left(\mathrm{C}_{6} \mathrm{H}_{6} \mathrm{O}\right)$, guaiacol $\left(\mathrm{C}_{7} \mathrm{H}_{8} \mathrm{O}_{2} ; 2\right.$-methoxyphenol), and syringol $\left(\mathrm{C}_{8} \mathrm{H}_{10} \mathrm{O}_{3} ; 2\right.$,6-dimethoxyphenol), respectively (see their structures in Table 1). The photochemical evolution of aqSOA mass and bulk composition is monitored using an Aerodyne high-resolution $(\sim 5000 \mathrm{~m} / \Delta \mathrm{m})$ timeof-flight aerosol mass spectrometer (HR-ToF-AMS, hereinafter referred to as AMS), while the molecular transformations of phenolic aqSOA are characterized using highresolution $(\sim 100000 \mathrm{~m} / \Delta \mathrm{m}$ at $m / z=400)$ nanospray desorption electrospray ionization mass spectrometry (nanoDESI MS) (Roach et al., 2010a, b). We examine the relationships between the average carbon oxidation state $\left(\mathrm{OS}_{\mathrm{C}}\right.$; Kroll et al., 2011) and number of carbon atoms $\left(n_{\mathrm{C}}\right)$ for aqSOA molecules observed during three different stages of aging to gain insights into the photochemical evolutions of phenolic aqSOA. In addition, the volatilities of the 50 most abundant molecules are estimated for each sample and a two-dimensional volatility basis set (2D-VBS) is used to describe the chemical evolution of phenolic aqSOA based on its volatility and $\mathrm{O} / \mathrm{C}$ ratio (Donahue et al., 2012; Jimenez et al., 2009).

\section{Experimental methods}

\subsection{Photochemical experiments and chemical analysis}

Aqueous oxidations were carried out using air-saturated solutions in stirred $110 \mathrm{~mL}$ Pyrex tubes under simulated sunlight illumination inside the RPR-200 photoreactor system discussed in George et al. (2015). The initial solution contained $100 \mu \mathrm{M}$ of a single phenol (i.e., $\mathrm{PhOH}$, GUA, or SYR) and was adjusted to $\mathrm{pH} 5$ using sulfuric acid. The initial concentration of phenol we chose is atmospheric relevant since the concentration of phenols and substituted phenols in cloud and fog waters were found to be in the range of $0.1-30 \mu \mathrm{M}$ (Anastasio et al., 1997; Sagebiel and Seiber, 1993) and in ar- 


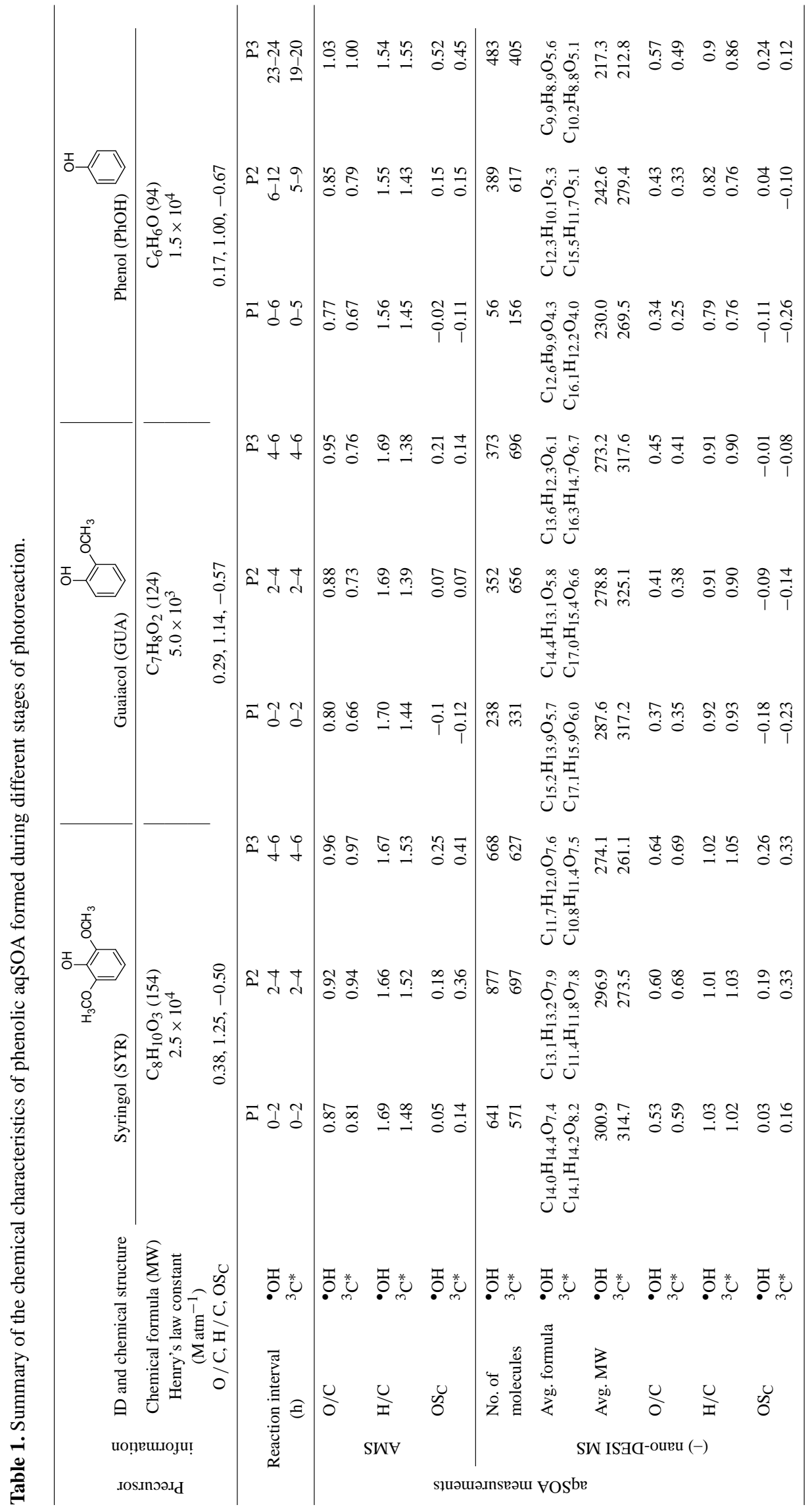


eas impacted by wood burning (e.g., in Northern California during wintertime), concentrations exceeding $100 \mu \mathrm{M}$ was predicted in fog waters (Anastasio et al., 1997). The $\mathrm{pH}$ of 5 is within the range of $\mathrm{pH}$ values observed in fog and cloud waters (Collett et al., 1999). Aqueous SOA was formed and evolved using two separate oxidants: (1) adding $100 \mu \mathrm{M}$ hydrogen peroxide $(\mathrm{HOOH})$ to the initial solution as a source of - $\mathrm{OH}$ and (2) adding $5 \mu \mathrm{M}$ 3,4-dimethoxybenzaldehyde (3,4DMB) as a source of ${ }^{3} \mathrm{C}^{*}$. The 3,4-DMB was chosen to represent non-phenolic aromatic carbonyls, which are emitted in large quantities from wood burning (Schauer et al., 2001), exist nearly exclusively in condensed phases in the atmosphere, and rapidly form ${ }^{3} \mathrm{C}^{*}$ that efficiently oxidizes phenols (Anastasio et al., 1997). The concentrations of phenols and 3,4-DMB are measured using a high-performance liquid chromatograph (HPLC) with a UV-visible detector. Details of the instrumentation and methodology are reported in Smith et al. (2014). In addition, $10.0 \mathrm{mg} \mathrm{L}^{-1}$ ammonium sulfate was added to each solution as an internal standard to relate aerosol concentration $\left(\mu \mathrm{g} \mathrm{m}^{-3}\right)$ measured by AMS to liquid concentration $\left(\mathrm{mg} \mathrm{L}^{-1}\right)$.

In order to compare the photochemical kinetics in the RPR-200 photoreactor system with that in the ambient, we calculated the steady-state concentrations of $\bullet \mathrm{OH}$ and the rate constant for the formation of ${ }^{3} \mathrm{C}^{*}$ in the RPR-200 photoreactor system. Detailed information is given in George et al. (2015). For ${ }^{3} \mathrm{C}^{*}$ exposure, the rate of light absorption is $\sim 7$ times faster in the RPR-200 photoreactor system than that in the midday winter solstice sunlight in Davis. The ${ }^{\bullet} \mathrm{OH}$ steady-state concentration in the RPR-200 photoreactor system under the reaction condition is $\sim 6.5$ times higher than the average fog water value, which is normalized to Davis winter solstice sunlight. Thus, the lifetime of phenolic precursors is $\sim 6.5$ times longer in the ambient fog water than that in RPR-200 photoreactor system.

Through the course of each experiment, a Shimadzu LC10AD HPLC pump was used to draw solution at a constant flow rate $\left(1.0 \mathrm{~mL} \mathrm{~min}^{-1}\right)$ alternatively from three identical illuminated tubes (total volume $=345 \mathrm{~mL}$ ) and one dark control tube covered with aluminum foil. The solution was delivered to a Collison atomizer, where pressurized argon was used to atomize the solution. The resulting aerosol was fully dried using a diffusion dryer and then divided into two flows. One aerosol flow was sampled and analyzed in real time by AMS at 1 min time resolution and the other passed through a Teflon filter to collect particles for offline analyses using nano-DESI MS. Three filters were collected at different time intervals over the course of each experiment; the sampling interval for each filter is given in Table 1. For SYR and GUA experiments, the illuminated solution was continuously aerosolized and sampled until it was exhausted after $\sim 6 \mathrm{~h}$. Since $\mathrm{PhOH}$ is much less reactive than SYR and GUA, with a 4-30 times longer half-life $\left(t_{1 / 2}\right)$ in aqueous phase (Smith et al., 2014; Yu et al., 2014), we conducted the PhOH experiments for a total of $20-24 \mathrm{~h}$ by sampling the illuminated solu- tion at $50 \%$ duty cycle (i.e., on and off every hour) during the first $9-12 h$ and the last $2 h$ of the experiment. Sampling was halted for $\sim 10 \mathrm{~h}$ while the solution was continuously illuminated. Details of AMS and nano-DESI MS measurements are given in Yu et al. (2014) and included in the Supplement. During each experiment, aliquots of the illuminated solution were also collected at defined time intervals and analyzed offline using an HPLC equipped with a UV-visible detector to monitor phenol concentrations.

\subsection{Determination of phenol reaction rates and aqSOA formation rates}

The initial rates of aqSOA formation and phenolic precursor decay were determined using an appropriate fit performed with Igor Pro 6.36 (Wavemetrics, Portland, OR, USA). The measured apparent first-order rate constant for phenol loss $\left(k_{\mathrm{d}}\right)$ was determined using an exponential decay fit to Eq. (1):

$[\mathrm{ArOH}]_{t} /[\mathrm{ArOH}]_{0}=\exp \left(-k_{\mathrm{d}} t\right)$,

where $[\mathrm{ArOH}]_{t}$ and $[\mathrm{ArOH}]_{0}$ are the measured concentrations of phenol at times $t$ and 0 , respectively. The initial destruction rate (i.e., at $t=0$ ) of phenol was therefore calculated as $R_{\mathrm{d}}=k_{\mathrm{d}} \times[\mathrm{ArOH}]_{0}$.

The apparent formation rate constant of phenolic aqSOA $\left(k_{\mathrm{f}}\right)$ was determined by fitting a three-parameter exponential rise to a maximum equation to the experimental data (Zhang and Anastasio, 2003):

[aqSOA $]=a-b \exp \left(-k_{\mathrm{f}} t\right)$,

where [aqSOA] is the concentration of aqSOA at time $t$, and $a, b$, and $k_{\mathrm{f}}$ are fitted parameters. The apparent initial formation rate of aqSOA was calculated as $R_{\mathrm{f}}=b \times k_{\mathrm{f}}$.

\subsection{Determination of aqSOA elemental ratios, $\mathrm{OS}_{\mathrm{C}}$, and $n_{\mathrm{C}}$}

The average atomic ratios of oxygen-to-carbon $(\mathrm{O} / \mathrm{C})$ and hydrogen-to-carbon $(\mathrm{H} / \mathrm{C})$ in bulk aqSOA were determined using AMS mass spectra (Aiken et al., 2008) as well as nanoDESI MS data (Bateman et al., 2012). Since we used argon as a carrier gas and removed physically bonded water molecules from the particles, we were able to determine the abundances of $\mathrm{CO}^{+}$and $\mathrm{H}_{2} \mathrm{O}$-related ions (i.e., $\mathrm{H}_{2} \mathrm{O}^{+}, \mathrm{HO}^{+}$, and $\mathrm{O}^{+}$) in the spectra of phenolic aqSOA directly (Yu et al., 2014; Sun et al., 2009). Thus, the $\mathrm{O} / \mathrm{C}$ and $\mathrm{H} / \mathrm{C}$ of aqSOA were determined without assuming relationships among $\mathrm{CO}^{+}, \mathrm{H}_{2} \mathrm{O}^{+}$ and $\mathrm{CO}_{2}^{+}$. Since the phenolic aqSOA studied here consist of only $\mathrm{C}, \mathrm{H}$, and $\mathrm{O}$ and the amount of peroxide groups was found to be negligible according to nano-DESI MS analysis, the average $\mathrm{OS}_{\mathrm{C}}$ is equal to $2 \times \mathrm{O} / \mathrm{C}-\mathrm{H} / \mathrm{C}$ (Kroll et al., 2011). According to Aiken et al. (2008), the average errors in the $\mathrm{O} / \mathrm{C}$ and $\mathrm{H} / \mathrm{C}$ values measured by the AMS are 31 and $10 \%$, respectively. The propagated error in $\mathrm{OS}_{\mathrm{C}}$ is estimated at $33 \%$. 
The molecular formulas of hundreds of individual aqSOA species were derived from nano-DESI MS acquired in the negative ion mode. The average $\mathrm{O} / \mathrm{C}, \mathrm{H} / \mathrm{C}$, and number of carbon atoms $\left(n_{\mathrm{C}}\right)$ in a given aqSOA sample were subsequently calculated by averaging across the individual values of each species weighted by the corresponding ion abundances in nano-DESI MS (Bateman et al., 2012). Comparisons of the average $\mathrm{O} / \mathrm{C}, \mathrm{H} / \mathrm{C}$, and $\mathrm{OS}_{\mathrm{C}}$ of aqSOA determined by AMS and nano-DESI MS are discussed in Appendix A.

\subsection{Estimation of volatilities of aqSOA molecules}

Based on the negative ion mode nano-DESI MS, we identified the 50 most abundant phenolic aqSOA molecules in each sample and estimated their volatilities. The molecular structure of each compound was proposed based on its molecular formula, double bond equivalent $(\mathrm{DBE}=\mathrm{C}-\mathrm{H} / 2+1)$, and chemical reasonability of the structure. The vapor pressures of the compounds at $298.15 \mathrm{~K}$ were subsequently estimated based on the Nannoolal vapor pressure and extrapolation method (Nannoolal et al., 2008, 2004) using the predictor available at http://www.aim.env.uea.ac.uk/aim/ddbst/ pcalc_main.php.

\section{Results and discussion}

\subsection{Photochemical evolution of aqSOA mass and elemental compositions}

Figure 1 provides an overview of the dynamics of phenol decay, aqSOA formation, and the evolution of aqSOA bulk composition (i.e., $\mathrm{O} / \mathrm{C}, \mathrm{H} / \mathrm{C}$, and $\mathrm{OS}_{\mathrm{C}}$ ) during each experiment. The reactions appear to follow first-order kinetics reasonably well (Fig. $1 \mathrm{a}-\mathrm{c}$ ) and the fitted rate constants and initial reaction rates are given in Table 2. Among all reactions, $\mathrm{SYR}+{ }^{3} \mathrm{C}^{*}$ is the fastest $\left(k_{\mathrm{d}}=2.0 \mathrm{~h}^{-1}\right.$ and $R_{\mathrm{d}}=$ $30 \mathrm{mg} \mathrm{SYR} \mathrm{L}^{-1} \mathrm{~h}^{-1}$, Table 2) and produces aqSOA at the highest rate $\left(k_{\mathrm{f}}=1.1 \mathrm{~h}^{-1}\right.$ and $R_{\mathrm{f}}=16 \mathrm{mg}$ aqSOA L $\left.{ }^{-1} \mathrm{~h}^{-1}\right)$. $\mathrm{PhOH}$ is much less reactive than SYR and forms aqSOA at initial rates more than 10 times slower. However, the slow reactions of $\mathrm{PhOH}$ allow the precursor to last longer and form aqSOA with higher overall yields (Fig. 1c). For instance, the aqSOA yields from SYR peak at 80-100\% after 3-4 h of reactions (Fig. 1a) while $\mathrm{PhOH}$ continues to produce aqSOA beyond $20 \mathrm{~h}$ of illumination with maximum yields reaching $140 \%$ (Fig. 1c). In a similar vein, under our conditions ${ }^{3} \mathrm{C}^{*}$ generally forms aqSOA more quickly than ${ }^{\bullet} \mathrm{OH}$ from oxidation of phenols (Table 2), although the increase in aqSOA mass tends to persist longer in ${ }^{\bullet} \mathrm{OH}$-mediated reactions.

As shown in Fig. 1d-1, the chemical composition of aqSOA evolves continuously throughout the course of photochemical aging. Note that $\mathrm{H} / \mathrm{C}, \mathrm{O} / \mathrm{C}$, and $\mathrm{OS}_{\mathrm{C}}$ are not reported for the beginning 10-15 min of the reactions because the aqSOA masses are low here, making the elemental ra- tios highly uncertain. Highly oxidized aqSOA species are formed immediately after the reactions start and the average $\mathrm{O} / \mathrm{C}$ of aqSOA are $0.26-0.49$ higher than the corresponding precursors after only $10-15 \mathrm{~min}$ of reactions (Fig. 1df). The quick formation of aqSOA is probably due to fast oligomerization coupled with addition of oxygenated functional groups. Indeed, previous studies have shown that phenolic aqSOAs present after illumination for one half-life $\left(t_{1 / 2}\right)$, which varies between $\sim 20 \mathrm{~min}$ for $\mathrm{SYR}+{ }^{3} \mathrm{C}^{*}$ and $\sim 6 \mathrm{~h}$ for $\mathrm{PhOH}$ reactions (Fig. 1a-c), are mainly composed of dimer, higher oligomers, and aromatic derivatives with a variety of oxygenated functional groups (Sun et al., 2010; Yu et al., 2014; George et al., 2015). The H / C values of aqSOA are also higher than those of the precursors (Fig. 1gi), suggesting hydrogen incorporation mechanisms which include electrophilic addition of the ${ }^{\bullet} \mathrm{OH}$ radical to the double bonds and electrophilic aromatic substitution reactions to attach more hydrogen-rich functional groups such as $-\mathrm{OCH}_{3}$ or $-\mathrm{C}(=\mathrm{O}) \mathrm{CH}_{3}$ to the benzene ring. This hypothesis is consistent with the results that the $\mathrm{H} / \mathrm{C}$ of aqSOA is generally higher in ${ }^{\bullet} \mathrm{OH}$-mediated reactions compared to ${ }^{3} \mathrm{C}^{*}$ reactions for the same precursor (Fig. $1 \mathrm{~g}-\mathrm{i}$ ) and that ${ }^{\bullet} \mathrm{OH}$-mediated reactions favor the open-ring process (Yu et al., 2014).

The $\mathrm{O} / \mathrm{C}$ and $\mathrm{OS}_{\mathrm{C}}$ of aqSOA increase throughout the reactions (Fig. 1d-f and $\mathrm{j}-1$ ), indicating the formation of increasingly more oxidized products over time. It is interesting to note that for the reactions of SYR with ${ }^{3} \mathrm{C}^{*}$ and ${ }^{\bullet} \mathrm{OH}$, the precursor is exhausted after $2.5-4 \mathrm{~h}$ of illumination (Fig. 1a) and a slow decay of aqSOA occurs shortly afterwards. By performing an exponential decay fit to the aqSOA curve between 3.1 and $5.9 \mathrm{~h}$, the lifetime of SYR aqSOA initiated with ${ }^{3} \mathrm{C}^{*}$ is estimated to be $\sim 5.3 \mathrm{~h}$. Note that the actual lifetime of aqSOA is likely somewhat shorter since 3,4-DMB was photochemically transformed during our experiment, although at a much slower rate. For example, measurements of 3,4-DMB concentration indicate that $\sim 70 \%$ of the original amount reacted after $\sim 6 \mathrm{~h}$ of illumination (Fig. S1 in the Supplement) and the products could include low-volatility species. In addition since the initial concentration of 3,4DMB is 20 times lower than that of the phenol precursor in our experiments, 3,4-DMB can only be a minor contributor to the observed aqSOA.

Unlike SYR, neither GUA nor $\mathrm{PhOH}$ is fully depleted throughout the experiments, and no plateau or decrease of aqSOA mass is observed (Fig. 1b and c). These results suggest that the overall rate of fragmentation reactions, which can convert some aqSOA species into semi-volatile and volatile molecules, is dependent on aqSOA concentration and that the production of phenolic aqSOA due to functionalization and oligomerization outweighs the loss of aqSOA due to fragmentation before the precursors are consumed. 


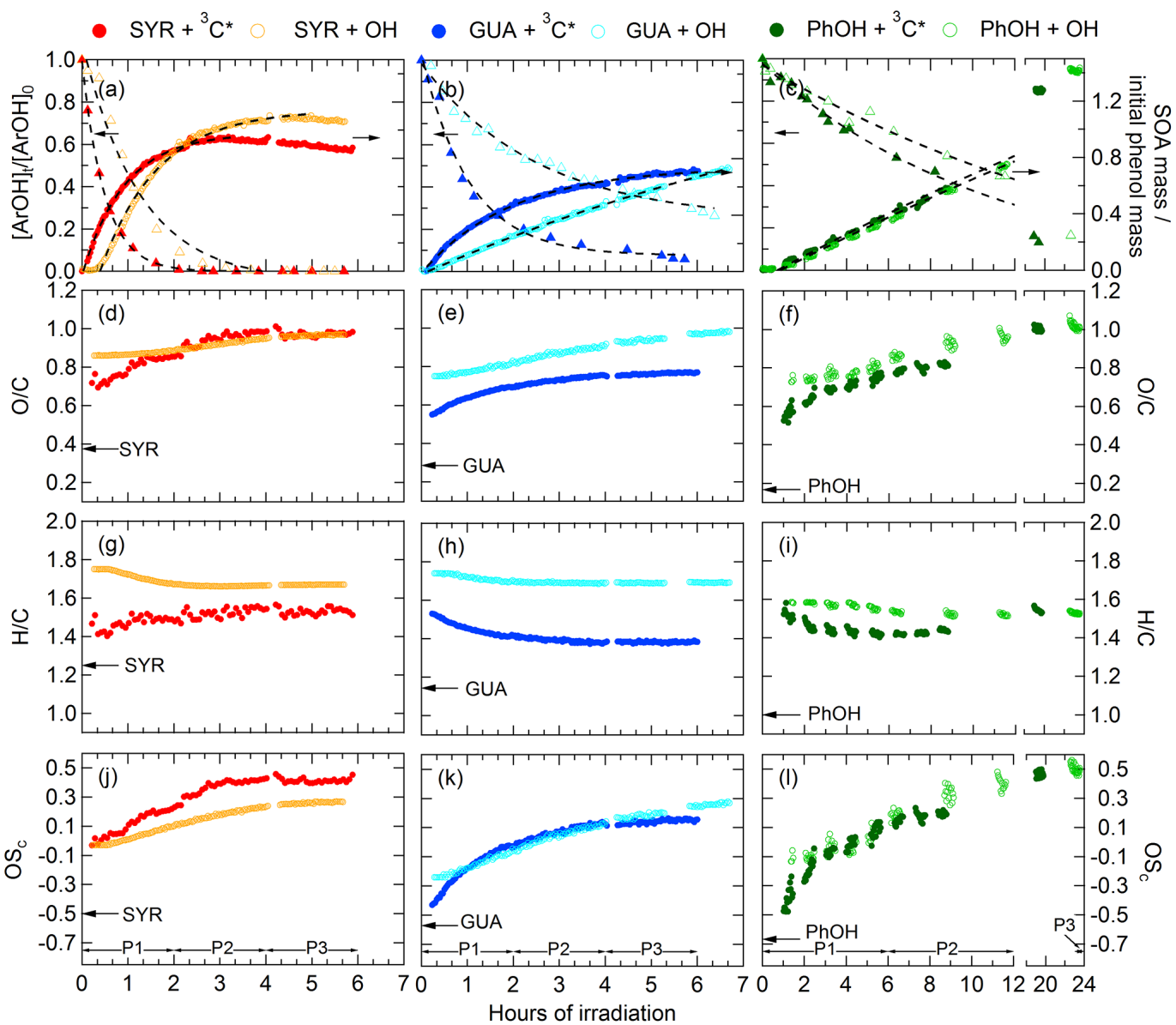

Figure 1. Evolution of (a-c) concentration of phenol precursors (left axes) and aqSOA mass (right axes) normalized by the initial concentration of precursor, (d-f) $\mathrm{O} / \mathrm{C}$ of aqSOA, (g-i) $\mathrm{H} / \mathrm{C}$ of aqSOA, and (j-l) $\mathrm{OS}_{\mathrm{C}}$ of aqSOA as a function of reaction time during individual experiments. The aqSOA mass and elemental ratios are determined from AMS data and precursor concentrations are measured by HPLC. In panels (a-c), phenol precursors are represented by solid and open triangles and aqSOA by solid and open circles. The two different oxidants are represented by the symbols shown in the legend on the top of the figure. The lines in panels (a-c) represent the regression fits to each set of experimental data and the fit parameters are summarized in Table 2. The $\mathrm{O} / \mathrm{C}, \mathrm{H} / \mathrm{C}$, and $\mathrm{OS}_{\mathrm{C}}$ values of individual phenolic precursors are indicated by the arrows in panels (d-l). The three reaction periods (P1-P3) for which filter samples were collected for nano-DESI MS analyses are marked in panels $(\mathbf{j}-\mathbf{l})$.

Table 2. Summary of the kinetics of the destructions of phenolic precursors and formation of aqSOA during simulated sunlight illumination. The error range calculation is based on the $95 \%$ confidential interval.

\begin{tabular}{|c|c|c|c|c|c|c|}
\hline & \multicolumn{2}{|c|}{ SYR } & \multicolumn{2}{|c|}{ GUA } & \multicolumn{2}{|c|}{$\mathrm{PhOH}$} \\
\hline & $\bullet \mathrm{OH}$ & ${ }^{3} C^{*}$ & $\bullet \mathrm{OH}$ & ${ }^{3} C^{*}$ & $\bullet \mathrm{OH}$ & ${ }^{3} \mathrm{C}^{*}$ \\
\hline $\begin{array}{l}\text { Rate constant of phenol } \\
\text { decay } k_{\mathrm{d}}\left(\mathrm{h}^{-1}\right)\end{array}$ & $0.80 \pm 0.2$ & $2.0 \pm 0.0$ & $0.40 \pm 0.08$ & $0.97 \pm 0.17$ & $0.05 \pm 0.02$ & $0.090 \pm 0.019$ \\
\hline $\begin{array}{l}\text { Initial decay rate of phenol } \\
R_{\mathrm{d}}\left(\mathrm{mg} \mathrm{L}^{-1} \mathrm{~h}^{-1}\right)\end{array}$ & $12 \pm 3.0$ & $30 \pm 0.6$ & $4.1 \pm 0.81$ & $10 \pm 1.8$ & $0.50 \pm 0.19$ & $0.91 \pm 0.19$ \\
\hline $\begin{array}{l}\text { Rate constant of aqSOA } \\
\text { formation } k_{\mathrm{f}}\left(\mathrm{h}^{-1}\right)\end{array}$ & $0.82 \pm 0.03$ & $1.1 \pm 0.03$ & $0.08 \pm 0.01$ & $0.51 \pm 0.01$ & $0.015^{\mathrm{a}}$ & $0.018^{\mathrm{a}}$ \\
\hline $\begin{array}{l}\text { Initial formation rate of } \\
\text { aqSOA } R_{\mathrm{f}}\left(\mathrm{mg} \mathrm{L}^{-1} \mathrm{~h}^{-1}\right)\end{array}$ & $14 \pm 0.53$ & $16 \pm 0.44$ & $1.6 \pm 0.20$ & $4.1 \pm 0.08$ & $0.65^{\mathrm{a}}$ & $0.82^{\mathrm{a}}$ \\
\hline
\end{tabular}

a The fitted value has very large uncertainty. 


\subsection{Molecular transformation during photochemical aging}

In order to gain further insights into the reaction mechanisms of phenolic aqSOA formation and aging, we used nano-DESI MS to investigate the molecular compositions of the aqSOA samples for each of the six phenol/oxidant combinations, with three samples collected over defined time intervals during each experiment. Figure 2 shows the negative ion mode nano-DESI mass spectra of these samples from which we calculate the signal-weighted average molecular formula for each sample. Table 1 summarizes the chemical characteristics of phenolic aqSOA during the different reaction stages. In addition, the molecular information of the 10 most abundant compounds in each aqSOA sample identified in the negative ion mode nano-DESI mass spectra are shown in Tables 3 and S1-S5.

Phenolic dimers and higher oligomers are detected in aqSOA from all stages of reactions, but these molecules become relatively less abundant at longer reaction times. This trend is seen more clearly in Fig. S2, where the signalweighted distributions of SYR, GUA, and $\mathrm{PhOH}$ aqSOA formed during different stages of photoreactions are shown based on the degree of oligomerization. There is a general trend that amounts of dimer, higher oligomers, and related derivatives decrease with reaction time, while oxygenated monomeric derivatives and open-ring species are significantly enhanced (Fig. 2). For example, as shown in Fig. 2a and b, SYR dimer $\left(\mathrm{C}_{16} \mathrm{H}_{18} \mathrm{O}_{6}\right.$; molecular weight $(\mathrm{MW})=306.1)$ is the most abundant species during the first $2 \mathrm{~h}$ of reaction but is absent in stages P2 (2-4h) and P3 (4-6h). In the meantime, the relative abundances of functionalized dimer molecules (e.g., $\mathrm{C}_{15} \mathrm{H}_{16} \mathrm{O}_{9} ; \mathrm{MW}=340.1$ ) and an open-ring species of SYR dimer (e.g., $\mathrm{C}_{15} \mathrm{H}_{18} \mathrm{O}_{7}$; $\mathrm{MW}=310.1$ ) show significant enhancements during $\mathrm{P} 2$ and $\mathrm{P} 3$, indicating that aqueous reactions both form and transform SYR oligomers. Similar behavior for the oligomeric products are also observed in the reactions of GUA and PhOH (Fig. 2b-f; Tables S1-S5), emphasizing the important role of oligomerization in forming phenolic aqSOA. During later stages of the reactions, the relative abundances of smaller, more oxidized aqSOA molecules, especially those with MW less than $200 \mathrm{Da}$ and $\mathrm{O} / \mathrm{C}>0.8$, increase substantially (Fig. 2), indicating that fragmentation reactions become more dominant over the course of photochemical aging. Indeed, as shown in Table 1, the average carbon number $\left(n_{\mathrm{C}}\right)$ of aqSOA generally decreases as a result of photochemical aging. For example, during the reaction of SYR $+{ }^{3} \mathrm{C}^{*}$ (Fig. 2a), the average molecular formula of the aqSOA formed between 0 and $2 \mathrm{~h}$ is $\mathrm{C}_{14.1} \mathrm{H}_{14.2} \mathrm{O}_{8.2}(\mathrm{MW}=314.7)$. Upon further illumination, from 2 to $4 \mathrm{~h}$, the average $n_{\mathrm{C}}$ and MW decrease to 11.4 and $273.5 \mathrm{Da}$, respectively, corresponding to an average molecular formula of $\mathrm{C}_{11.4} \mathrm{H}_{11.8} \mathrm{O}_{7.8}$. For the last reaction stage of illumination (4-6h), the average $n_{\mathrm{C}}$ and MW continue to decrease and the average molecular for- mula becomes $\mathrm{C}_{10.8} \mathrm{H}_{11.4} \mathrm{O}_{7.5}$ (average $\mathrm{MW}=261.1$; Table 1 and Fig. 2).

The molecular information of the 10 most abundant compounds in SYR $+{ }^{3} \mathrm{C}^{*}$ aqSOA identified in the positive ion mode nano-DESI mass spectra is shown in Table S6. Note that the positive ion mode nano-DESI MS results give similar molecular formulas for the dominant dimer and dimeric derivatives as those detected under the negative ion mode measurements. However, a number of open-ring species that have high abundance in the negative nano-DESI mass spectra are not detected among the top 10 most abundant products in the positive ion mode nano-DESI spectra. This is likely due to the fact that open-ring species, such as organic acids, are more likely to deprotonate than protonate, and therefore they are more likely to be detected through the negative ion mode nano-DESI MS analysis.

A previous study suggests that oligomerization could potentially occur during the electrospray ionization process (Yasmeen et al., 2010). In this study, we analyzed the dark control solutions using ESI-MS via direct infusion. Dimer and higher oligomers are not identified in the ESI mass spectra of dark control samples. In addition, tracer ions of dimer and high oligomers are identified in AMS spectra of phenolic aqSOA as well (Yu et al., 2014). Thus, it is certain that the phenolic oligomers observed in this study are generated through aqueous photochemistry rather than being an artifact of the ESI process.

\subsubsection{Photochemical aging of phenolic aqSOA in the $\mathrm{OS}_{\mathrm{C}}-\boldsymbol{n}_{\mathrm{C}}$ framework}

The average carbon oxidation state, $\mathrm{OS}_{\mathrm{C}}$, has been proposed as a metric for describing the chemistry of atmospheric organic aerosol and its relationship to $n_{\mathrm{C}}$ reveals useful insights into the chemical aging of OA (Kroll et al., 2011). We therefore examined the molecular compositions of aqSOA in the $\mathrm{OS}_{\mathrm{C}}$ vs. $n_{\mathrm{C}}$ space during different stages of aging for each sample based on results from the nano-DESI MS. Figure 3 shows an example of this for the aqSOA molecules generated from the SYR $+{ }^{3} \mathrm{C}^{*}$ reaction; the $\mathrm{OS}_{\mathrm{C}}$ vs. $n_{\mathrm{C}}$ plots for the other five experiments are shown in Figs. S3-S7. These figures show that the aqSOA of phenols are composed of molecules covering a wide range of $n_{\mathrm{C}}$ and $\mathrm{OS}_{\mathrm{C}}$, some of which overlap with regions corresponding to ambient LVOOA and SV-OOA reported as Kroll et al. (2011). However, there is very little overlap between aqSOA and BBOA or HOA in this space (Figs. 3 and S3-S7), despite the fact that phenols are a major constituent in biomass burning emissions (Schauer et al., 2001). This result is consistent with the fact that primary and secondary organic aerosols are very different chemically, especially in terms of oxidation degree. The $\mathrm{OS}_{\mathrm{C}}-n_{\mathrm{C}}$ diagrams also illustrate that with increasing reaction time, the abundance of highly oxidized small molecules with $n_{\mathrm{C}}<6$ is significantly enhanced, while the abundance of 
(a) SYR $+{ }^{3} \mathrm{C}^{*}$
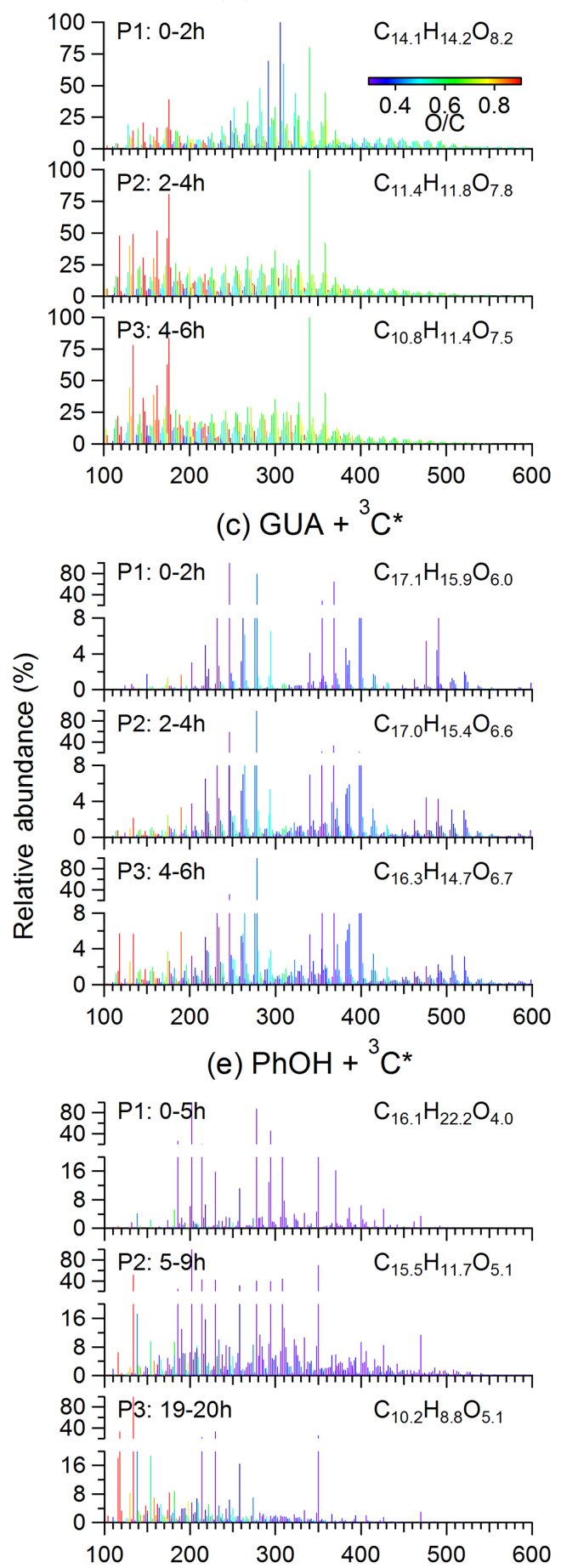

(b) $\mathrm{SYR}+\cdot \cdot \mathrm{OH}$

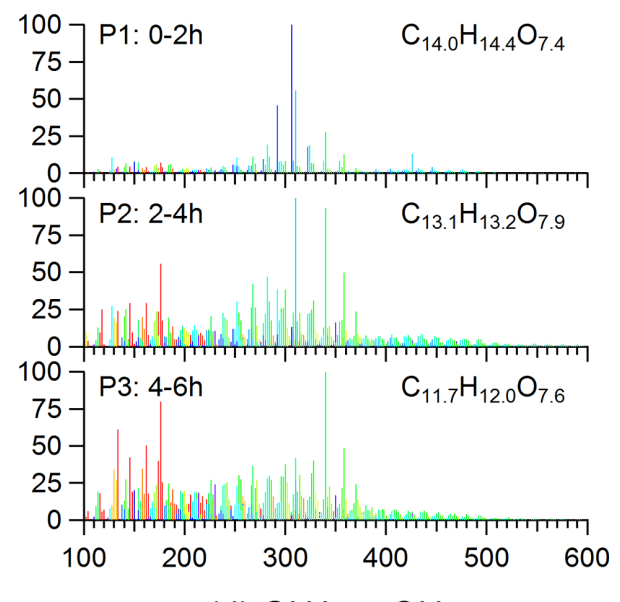

(d) $\mathrm{GUA}+\cdot \cdot \mathrm{OH}$
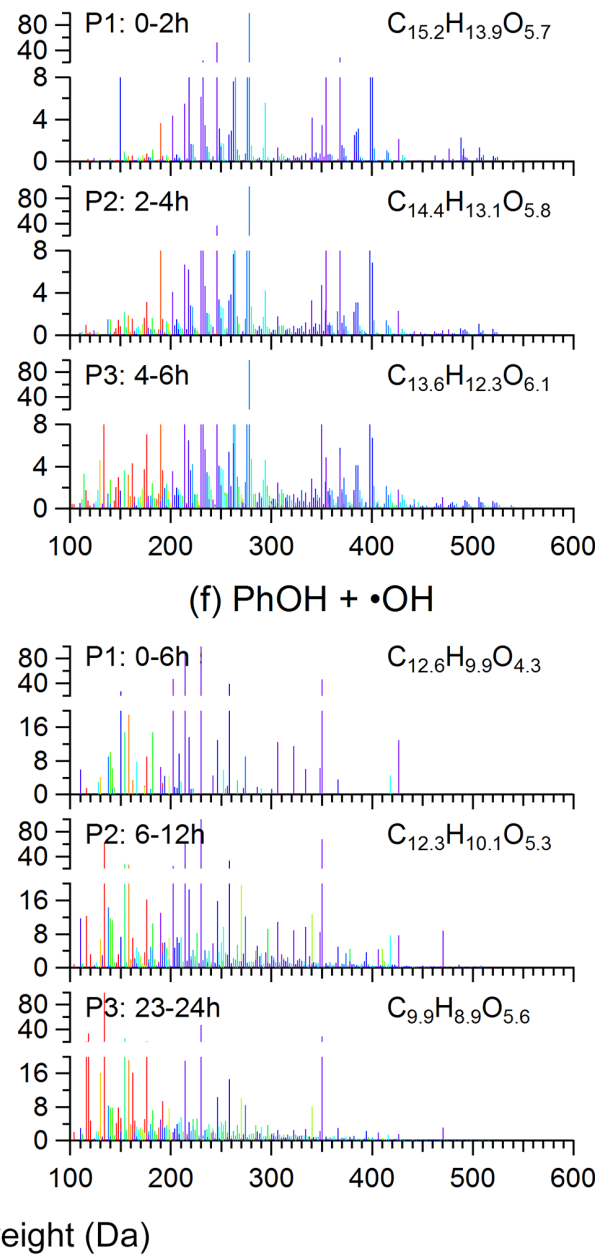

Figure 2. Negative ion mode nano-DESI mass spectra of phenolic aqSOA formed during different stages of photoreaction. Signals are colored by the $\mathrm{O} / \mathrm{C}$ ratios of the molecules. The signal-weighted average molecular formula of each aqSOA is shown in the legends. 
(-) DESI SYR $+{ }^{3} \mathrm{C}^{*}$
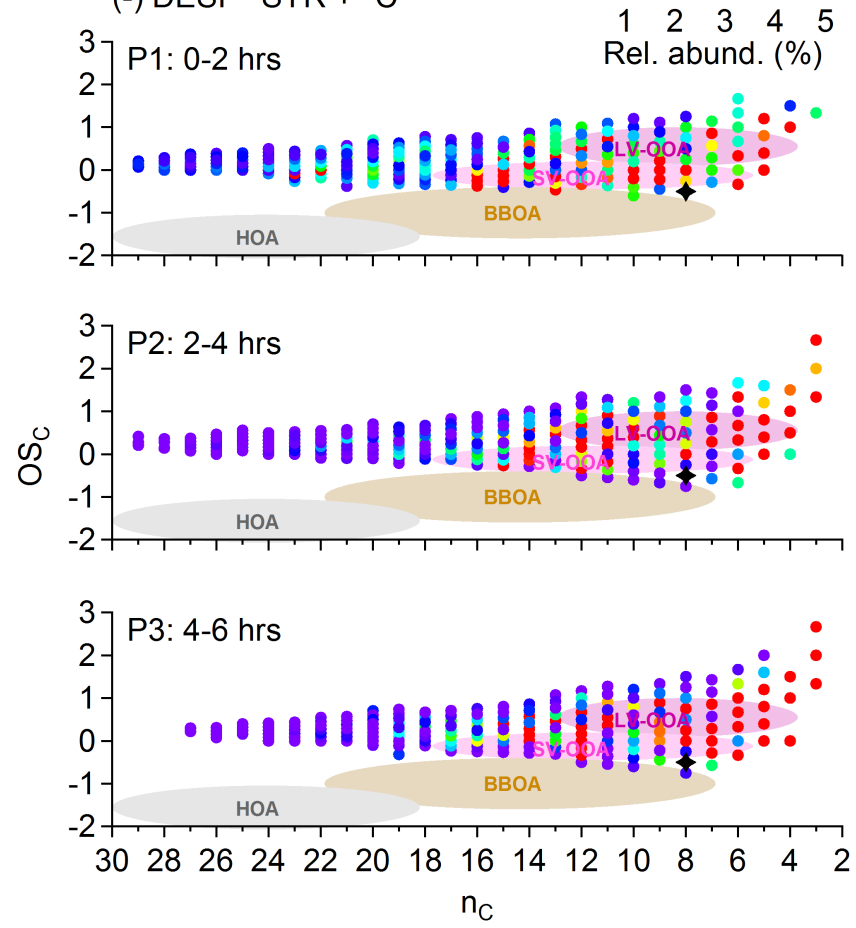

Figure 3. $\mathrm{OS}_{\mathrm{C}}$ and $n_{\mathrm{C}}$ of molecules in SYR aqSOA formed during different stages of ${ }^{3} \mathrm{C}^{*}$-mediated reactions determined based on (-) nano-DESI MS spectra. Signals are colored by the relative abundance of the molecules. The black star at $n_{\mathrm{C}}=8$ represents SYR. The shaded ovals indicate locations of different ambient organic aerosol classes reported in Kroll et al. (2011).

less oxidized, high molecular weight species with $n_{\mathrm{C}}>18$ is significantly reduced.

Since each phenolic aqSOA is composed of thousands of product molecules, we examine the evolution pattern of bulk aqSOA by mapping the average $\mathrm{OS}_{\mathrm{C}}$ determined from AMS with respect to the average $n_{\mathrm{C}}$ from nano-DESI MS for different stages of photoreactions (Fig. 4). There is a general trend that photochemical aging converts phenolic aqSOA into smaller and more oxidized species and that the average $\mathrm{OS}_{\mathrm{C}}$ and average $n_{\mathrm{C}}$ of the aqSOA of different precursors appear to converge on the $\mathrm{OS}_{\mathrm{C}}-n_{\mathrm{C}}$ map as a result of aging. In addition, the average ${ } S_{C}$ values of phenolic aqSOA all fall within the range observed for ambient SOA, generally moving in the direction from SV-OOA toward LV-OOA. Note that we observe good agreement between nano-DESI MS and AMS for average $\mathrm{OS}_{\mathrm{C}}$ determination, as discussed in Appendix A.

\subsubsection{Photochemical aging of phenolic aqSOA in the O / C-H / C framework}

The molecular transformation of phenolic aqSOA can also be examined in the $\mathrm{O} / \mathrm{C}$ vs. $\mathrm{H} / \mathrm{C}$ space using van Krevelen diagrams (Fig. 5). As illustrated by the SYR $+{ }^{3} \mathrm{C}^{*}$ reaction, the

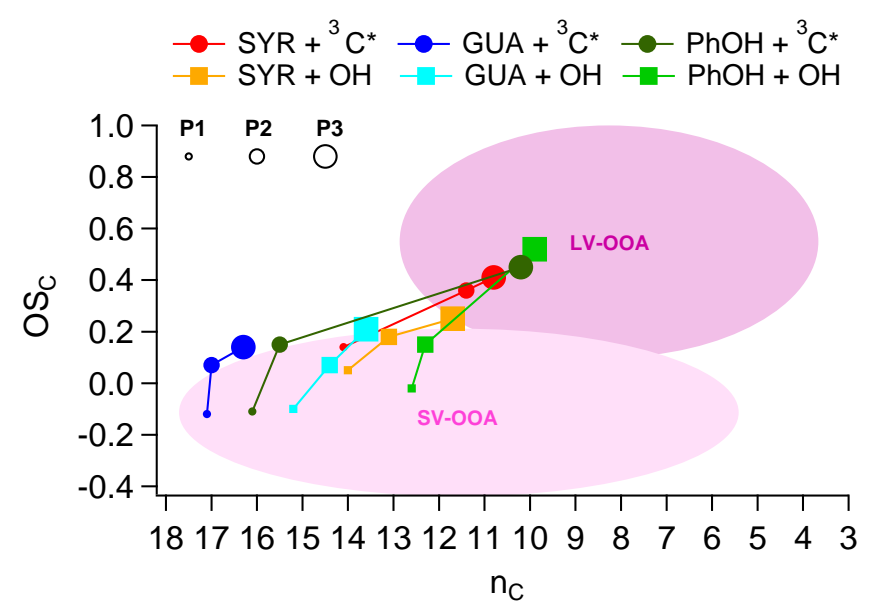

Figure 4. Average $\mathrm{OS}_{\mathrm{C}}$ and $n_{\mathrm{C}}$ of phenolic aqSOA formed during different stages of ${ }^{3} \mathrm{C}^{*}$ - and ${ }^{\bullet} \mathrm{OH}$-mediated reactions. The $\mathrm{OS}_{\mathrm{C}}$ values were determined based on the AMS data and the $\mathrm{nC}$ based on (-) nano-DESI MS data. The different phenolic and oxidant conditions are represented by the symbols shown in the legend. The symbol sizes increase with irradiation time. The shaded ovals indicate regions of LV-OOA and SV-OOA reported in Kroll et al. (2011).

initial aqSOA ( $0-2 \mathrm{~h}$ of photoreaction) is dominated by large molecules $\left(n_{\mathrm{C}}>14\right)$ located in the lower part of the diagram (lower O / C; Fig. 5a), while aqSOA in the last time interval (4-6h) is dominated by highly oxidized open-ring species $\left(n_{\mathrm{C}}<6\right)$, with most signal located in the upper part of the diagram (higher $\mathrm{O} / \mathrm{C}$ ). Based on $n_{\mathrm{C}}$ and DBE, these highly oxidized small molecules are likely carboxylic acids formed from the oxidation and fragmentation of larger molecules (Table 3). These results indicate that longer aging leads to more oxidation, functionalization, and fragmentation. Fragmentation eventually gains importance over functionalization, forming a large number of highly oxidized open-ring species $\left(n_{\mathrm{C}}<6\right)$ by the final time. This is also consistent with AMS results, which show quick formation of aqSOA due to oligomerization and functionalization, followed by fragmentation, and a general decrease in aqSOA mass, at later times (see Sect. 3.1). These results are consistent with previous findings that the higher MW oligomeric SOA compounds are subjected to photodegradation via photolysis (Romonosky et al., 2015; Lee et al., 2014).

\subsection{Volatility distribution and transformation with photochemical aging}

Since the chemical composition of aqSOA evolves with photochemical aging, we also investigated how these transformations affect the volatility of phenolic aqSOA. Saturation concentrations $\left(C^{*}, \mu \mathrm{g} \mathrm{m}^{-3}\right)$ were estimated for the 50 most abundant aqSOA species in each phenol/oxidant combination, as shown in Fig. 5 in an $\mathrm{O} / \mathrm{C}$ vs. $\log _{10}\left(C^{*}\right.$, $\mu \mathrm{g} \mathrm{m}^{-3}$ ) volatility basis set space (Pankow and Barsanti, 2009). The $C^{*}$ of these molecules vary by $\sim 10^{23}$, rang- 

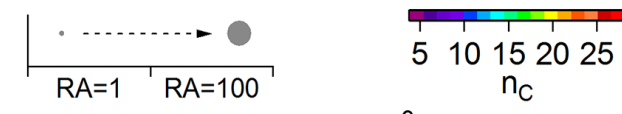

(a) $\mathrm{SYR}+{ }^{3} \mathrm{C}^{*}$
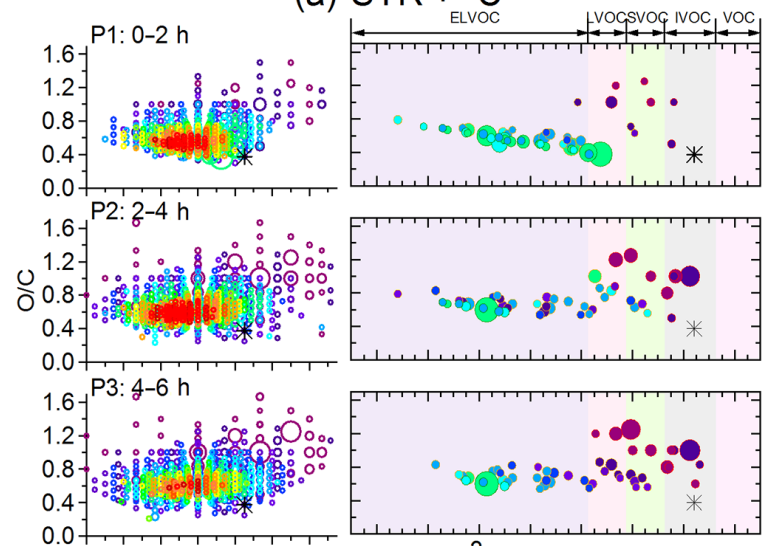

(c) GUA $+{ }^{3} \mathrm{C}^{*}$

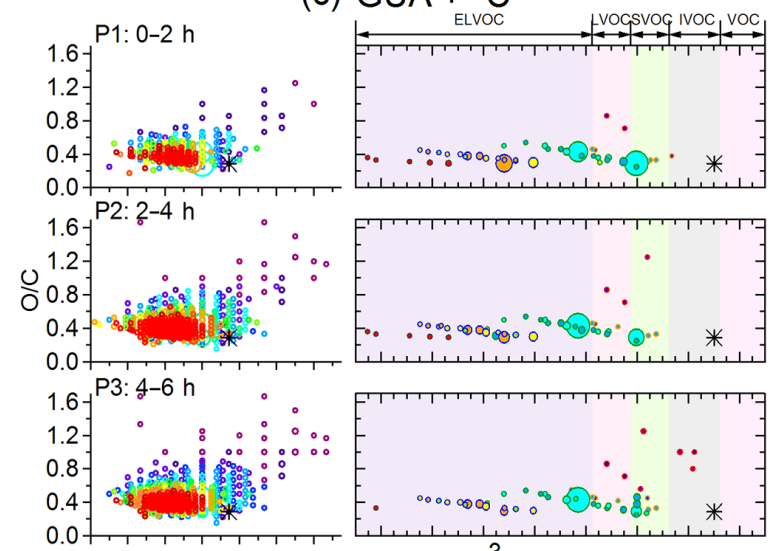

(e) $\mathrm{PhOH}+{ }^{3} \mathrm{C}^{*}$

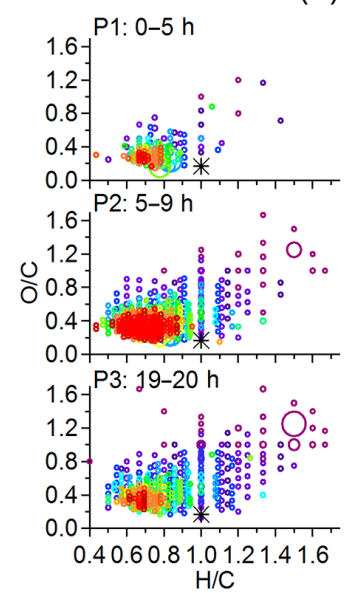

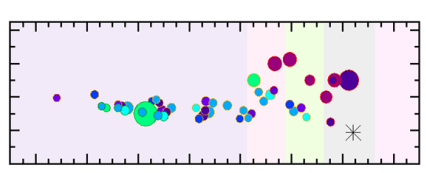
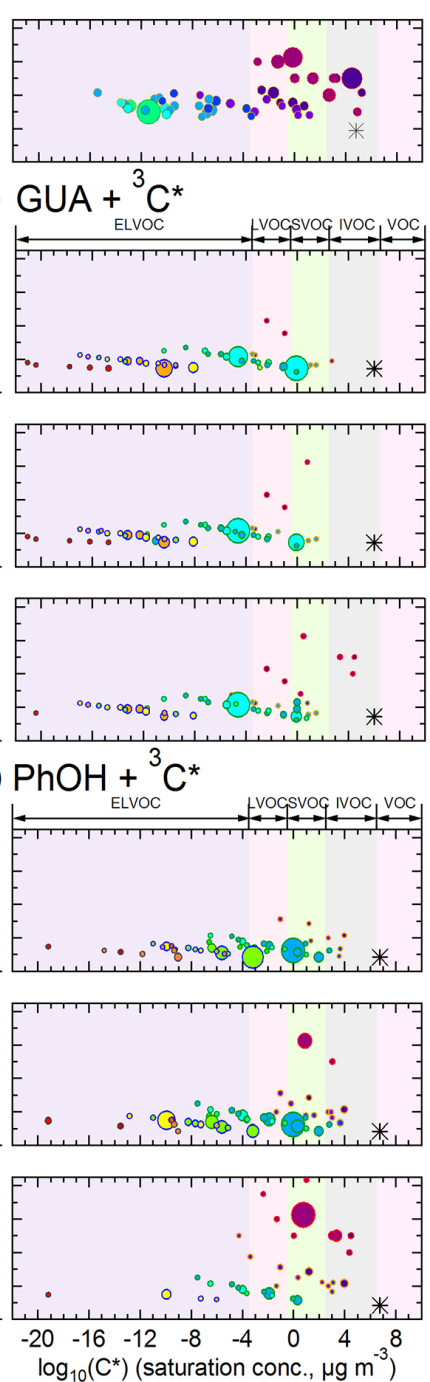

Open-ring species $\left(\mathrm{n}_{\mathrm{C}}<6\right) \quad$ Trimer \& deriv. Monomer deriv.

Dimer \& deriv.

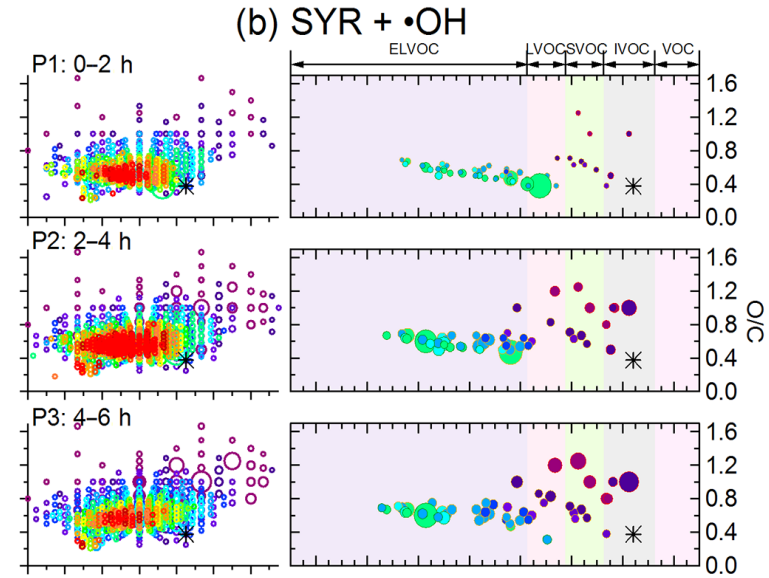

(d) $\mathrm{GUA}+\cdot \cdot \mathrm{OH}$
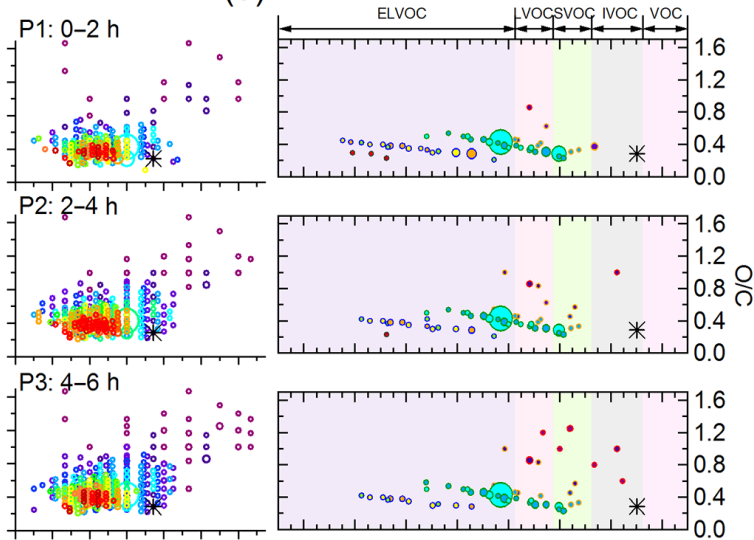

(f) $\mathrm{PhOH}+\cdot \cdot \mathrm{OH}$

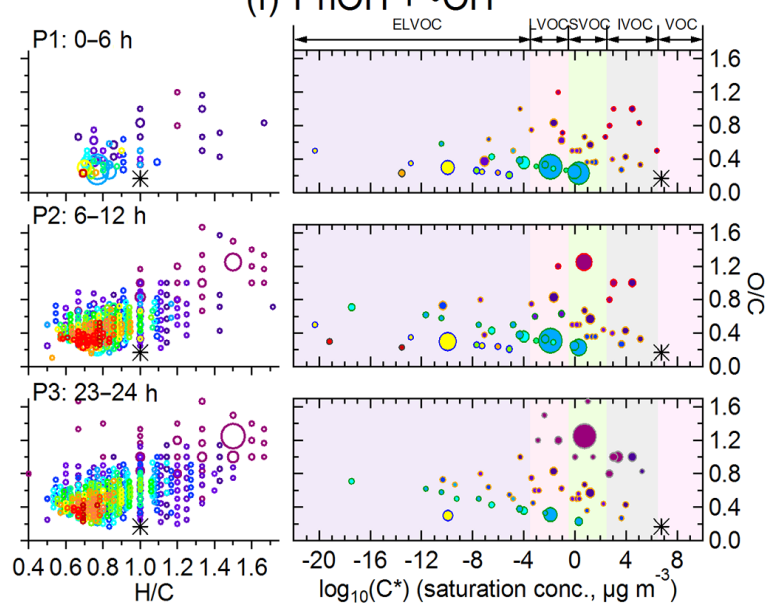

Figure 5. $\mathrm{O} / \mathrm{C}$ and $\mathrm{H} / \mathrm{C}$ of SYR, GUA, and $\mathrm{PhOH}$ aqSOA molecules formed during three different stages of the ${ }^{3} \mathrm{C}^{*}$-and $\bullet$ OH-mediated reactions. To the right of each $\mathrm{O} / \mathrm{C}$ vs. $\mathrm{H} / \mathrm{C}$ plot is a plot that shows the $\mathrm{O} / \mathrm{C}$ and volatility $\left(\log _{10} C^{*}\right.$ in $\left.\mu \mathrm{g} \mathrm{m}{ }^{-3}\right)$ for the 50 most abundant aqSOA molecules. On the $\mathrm{O} / \mathrm{C}$ vs. $C^{*}$ plots, the volatility ranges are indicated by colored bands: (1) extremely low-volatile organic compounds (ELVOC; $C^{*}<3.2 \times 10^{-4} \mu \mathrm{g} \mathrm{m}^{-3}$ ), (2) low-volatility organic compounds (LVOC; $3.2 \times 10^{-4} \mu \mathrm{g} \mathrm{m}^{-3}<C^{*}<0.32 \mu \mathrm{g} \mathrm{m}^{-3}$ ), (3) semivolatile organic compounds (SVOC; $0.32 \mu \mathrm{g} \mathrm{m}^{-3}<C^{*}<320 \mu \mathrm{g} \mathrm{m}^{-3}$ ), (4) IVOC $\left(320 \mu \mathrm{g} \mathrm{m}^{-3}<C^{*}<3.2 \times 10^{6} \mu \mathrm{g} \mathrm{m}^{-3}\right.$ ), and (5) volatile organic compounds (VOC; $C^{*}>3.2 \times 10^{6} \mu \mathrm{g} \mathrm{m}^{-3}$ ). On the $\mathrm{O} / \mathrm{C}$ vs. $C^{*}$ plots, the degree of oligomerization for each species is represented by the stroke color. On both $\mathrm{O} / \mathrm{C}$ vs. $\mathrm{H} / \mathrm{C}$ and $\mathrm{O} / \mathrm{C}$ vs. $C^{*}$ plots, sizes of points are scaled by the relative abundance (RA) and colored by the number of carbon atoms $\left(n_{\mathrm{C}}\right)$. The black stars represent phenolic precursors. 


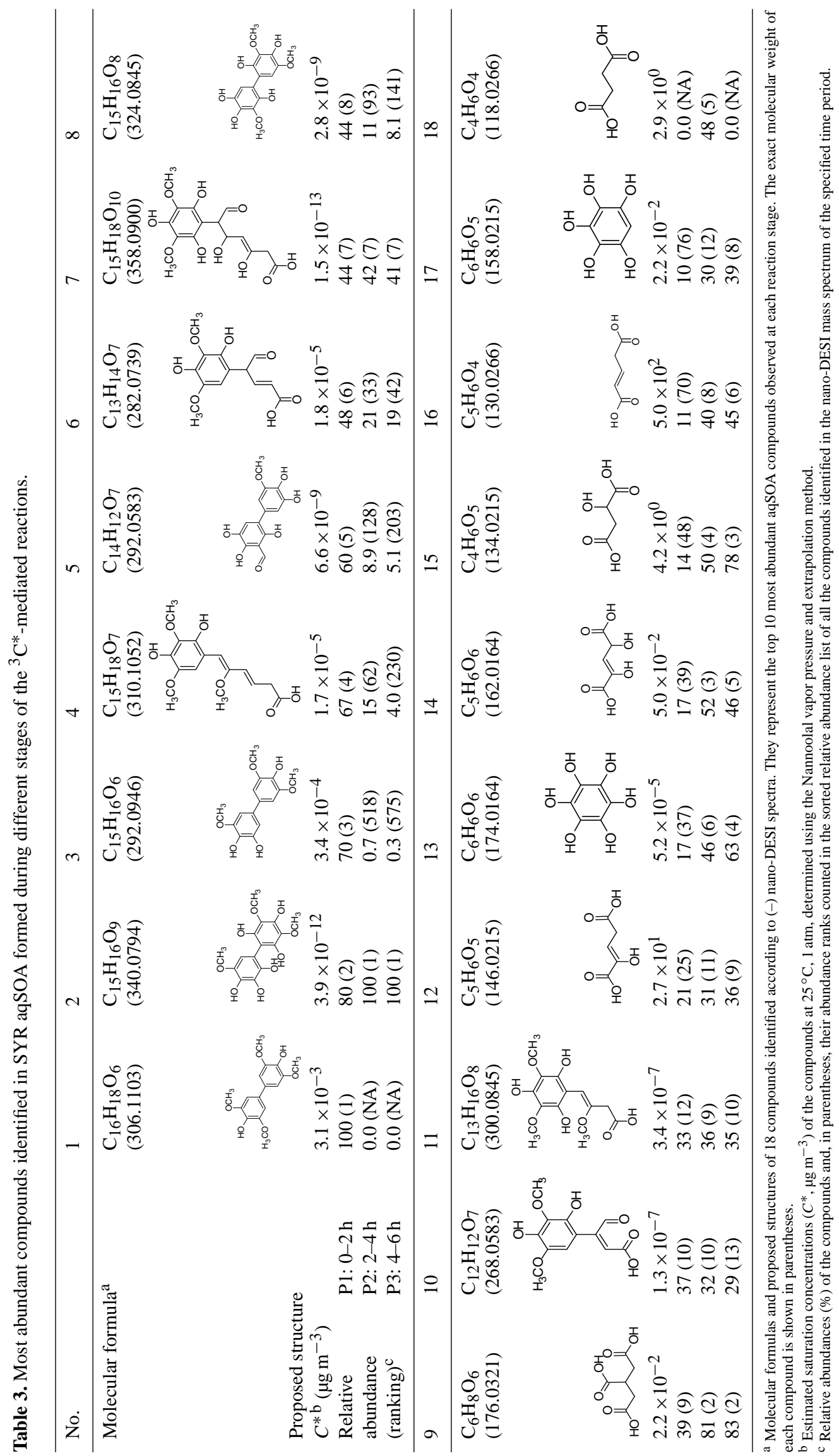


(a)

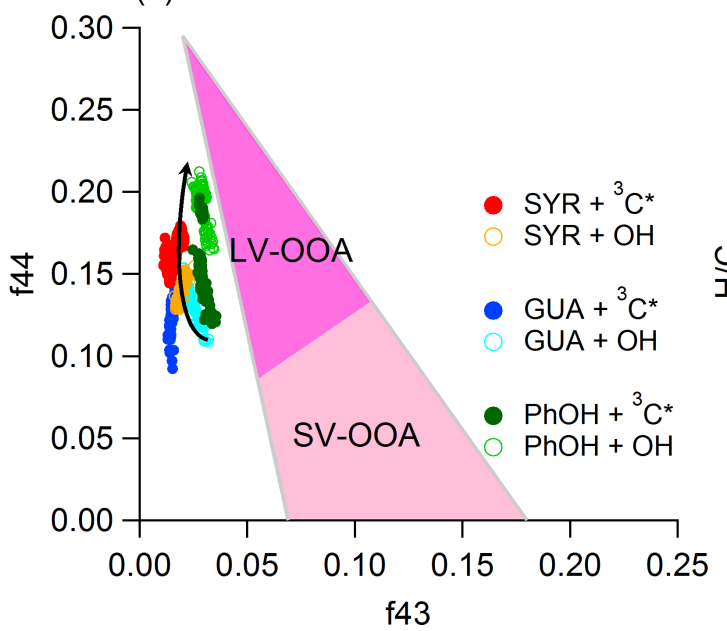

(b)

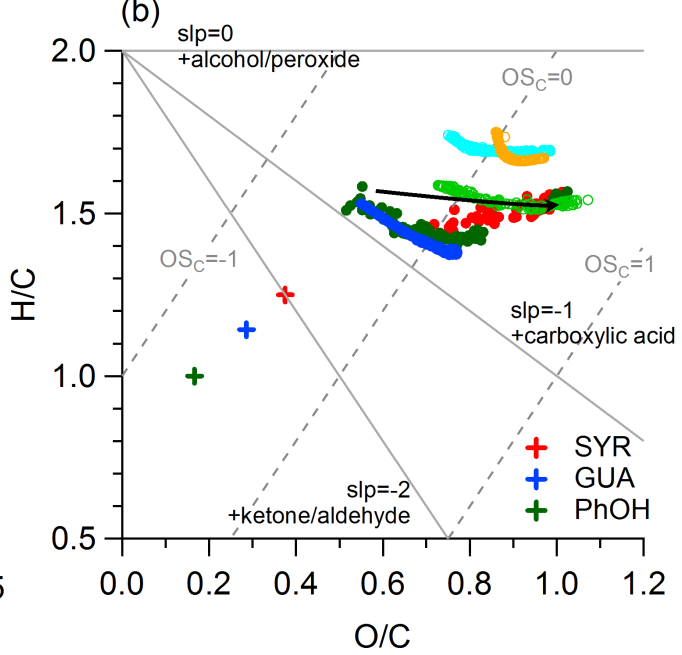

Figure 6. Evolution profiles of phenolic aqSOA in (a) the $f_{44}$ vs. $f_{43}$ space and (b) the $\mathrm{H} / \mathrm{C}$ vs. O / C space based on AMS measurements. The shaded triangle in (a) defines the region where typical ambient SOA lie (Ng et al., 2010). Different experimental conditions are represented by the symbols shown in the legend. Phenolic precursors are represented by the "+" symbols in (b). Lines with slopes of 0 , -1 , and -2 indicate the addition of alcohol/peroxide, carboxylic acid, and ketone/aldehyde functional group, respectively. Dashed lines indicate OS $_{\mathrm{C}}$ of $-1,0$, and 1 , respectively.

ing from $<10^{-22} \mu \mathrm{g} \mathrm{m}^{-3}$ (e.g., functionalized phenolic oligomers) to $>10 \mu \mathrm{g} \mathrm{m}^{-3}$ (e.g., highly oxygenated openring species with $n_{\mathrm{C}}<6$ ). The volatility distribution clearly changes during photochemical aging. For example, SYR aqSOA formed at the initial stage is dominated by the dimer and oxygenated derivatives with $C^{*}$ values corresponding to the low-volatility $\left(C^{*}=3.2 \times 10^{-4}-0.32 \mu \mathrm{g} \mathrm{m}^{-3}\right.$; Donahue et al., 2012) and extremely low-volatile organic compounds (ELVOC; $C^{*}<3.2 \times 10^{-4} \mu \mathrm{g} \mathrm{m}^{-3}$; Donahue et al., 2012) regions. After $\sim 4 \mathrm{~h}$ of illumination, the number and abundance of intermediate-volatility $\left(C^{*}=320-3.2 \times 10^{6} \mu^{-3} \mathrm{~m}^{-3}\right.$; Donahue et al., 2012) and semi-volatile $\left(C^{*}=0.32-320 \mu \mathrm{g} \mathrm{m}^{-3}\right.$; Donahue et al., 2012) highly oxygenated open-ring species $\left(n_{\mathrm{C}}<6\right)$ are significantly enhanced. However, some of the high $n_{\mathrm{C}}$ compounds, such as dimeric derivative $\mathrm{C}_{15} \mathrm{H}_{16} \mathrm{O}_{9}$, which is classified as an ELVOC according to $C^{*}$, still remain in large abundance at the later stage. This is consistent with AMS results, which show that although photochemical aging leads to a slight decrease of SYR aqSOA mass after the precursor is consumed, significant amount of aqSOA mass still remain after illumination equivalent to several days of tropospheric aging (more details are discussed in Sect. 3.1). These results suggest that the photochemical aging increases the volatility of aqSOA by forming a large number of intermediate-volatile and semi-volatile open-ring species $\left(n_{\mathrm{C}}<6\right)$, while a number compounds with extremely low volatility are relatively recalcitrant.

\section{Conclusions and atmospheric implications}

In this study, we investigated the molecular transformations of phenolic aqueous SOA during oxidative aging. Overall, aqueous reactions of phenols form highly oxidized aqSOA at fast rates and aqSOA becomes increasingly oxidized during continued oxidative processing. In order to compare our results with atmospheric observations, in Fig. 6a we map the aqueous aging of phenolic aqSOA on the $f_{44}$ (ratio of ion signal at $m / z=44$ to total organic signal in the mass spectrum) vs. $f_{43}$ (defined similarly) space. $\mathrm{Ng}$ et al. (2010) used the $f_{44}$ vs. $f_{43}$ space ("triangle plot") to present the OA factors from PMF analysis of 43 northern hemispheric AMS data sets of organic aerosol. In the triangle plot, the less aged SV-OOA generally occupies the broader base of the triangle (likely due to the variable composition of fresher SOA formed from site-specific precursors and sources) and the highly oxidized, more atmospherically aged LV-OOA occupies the narrowing top region of the triangle. Our results show that aqueous reactions of phenols produce highly oxidized species with $f_{44}$ values close to ambient LV-OOA but lower $f_{43}$ (Fig. 6a). The evolution pathways of phenolic aqSOA formed under the different reaction conditions all move upward in this space and have a tendency to converge towards the peak of the triangle. These results are consistent with previous findings that ambient oxidation eventually leads to the formation of OOA with similar chemical composition regardless of the source ( $\mathrm{Ng}$ et al., 2010). Figure 6b shows the van Krevelen diagram of the average elemental ratios of phenolic aqSOA measured by AMS for the ${ }^{3} \mathrm{C}^{*}$ - and - $\mathrm{OH}$-mediated reactions. The $\mathrm{O} / \mathrm{C}$ and $\mathrm{H} / \mathrm{C}$ ratios of phe- 
nolic aqSOA appear to evolve nearly horizontally on the van Krevelen diagram space, suggesting that hydroxylation is a dominant reaction pathway during the aging process. This conclusion is consistent with nano-DESI MS results, which demonstrate the presence of a wide range of abundant hydroxylated molecules in phenolic aqSOA.

Overall, our results demonstrate that photochemical aging significantly transforms the chemical composition and volatility distribution of phenolic aqSOA. Based on the bulk and molecular results, phenolic aqSOA evolves dynamically during photochemical aging, with different reaction pathways (oligomerization, fragmentation, and functionalization) leading to different generations of products that span an enormous range in volatilities and a large range in oxidation state and composition. Yee et al. (2013) investigated the photooxidation of phenols under low- $\mathrm{NO}_{x}$ condition, and hydrogen peroxide was used as the ${ }^{\bullet} \mathrm{OH}$ precur- sor. The major reaction pathways include demethoxylation and open-ring process, and oligomer formation is not observed in ${ }^{\bullet} \mathrm{OH}$-initiated oxidation of phenols in the gas phase (Yee et al., 2013). The detection of a number of compound with $C^{*}<3.2 \times 10^{-4} \mu \mathrm{g} \mathrm{m}^{-3}$ suggests that aqueous reactions of phenolic compounds are likely an important source of ELVOC in the atmosphere, especially in regions strongly influenced by biomass burning emissions. While some of these smaller, highly oxygenated species will be released to the gas phase, even at the longest aging times the samples contain large, low-volatility derivatized oligomers that are quite recalcitrant to fragmentation. The presence of presumably hygroscopic hydroxylated carboxylic acids suggests these phenolic products might influence water uptake in particles downwind of biomass burning. It is unclear whether the products we identified here might influence the health effects of ambient particles. 
Appendix A: Comparisons between AMS and nano-DESI MS for average aqSOA elemental composition analysis

Figure A1 compares the average $\mathrm{O} / \mathrm{C}, \mathrm{H} / \mathrm{C}$, and $\mathrm{OS}_{\mathrm{C}}$ values, and the changes of these quantities (i.e., $\Delta \mathrm{O} / \mathrm{C}$, $\Delta \mathrm{H} / \mathrm{C}$, and $\Delta \mathrm{OS}_{\mathrm{C}}$ ) between different reactions stages, of the 18 aqSOA samples measured by the AMS vs. the values from the nano-DESI MS. The average $\mathrm{O} / \mathrm{C}$ and $\mathrm{H} / \mathrm{C}$ determined from nano-DESI MS are systematically lower than the values measured by AMS. Although the correlation between the two instruments is relatively good $\left(r^{2}=0.58\right.$; Fig. A1a) for $\mathrm{O} / \mathrm{C}$, it is generally poor for $\mathrm{H} / \mathrm{C}\left(r^{2}=0.12\right.$; Fig. A1b). In addition, $\Delta \mathrm{O} / \mathrm{C}$ and $\Delta \mathrm{OS}_{\mathrm{C}}$ also appear to be systematically lower according to nano-DESI MS compared to AMS, but the two sets of values arevery well correlated $\left(r^{2}=0.84\right.$
0.89; Fig. A1d-f). These discrepancies likely arise from the large differences between the AMS and the nano-DESI MS methodology, in terms of sample analysis, data processing, and the assumptions used for calculating the average elemental ratios. For example, the assumption of equal ionization efficiency for all molecules by the nano-DESI (Bateman et al., 2012) may have limitations. In addition, molecules smaller than $100 \mathrm{Da}$, most of which are highly oxidized, were outside of the operational mass range of nano-DESI MS. Nevertheless, it is interesting to note that the $\mathrm{OS}_{\mathrm{C}}$ for phenolic aqSOA determined by nano-DESI MS and AMS agree well $\left(r^{2}=0.71\right.$, slope $=1.01 ;$ Fig. A1c). This agreement between the two methods for average $\mathrm{OS}_{\mathrm{C}}$ determination suggests that $\mathrm{OS}_{\mathrm{C}}$ is a more robust quantity for reporting average oxidation of organic aerosols.
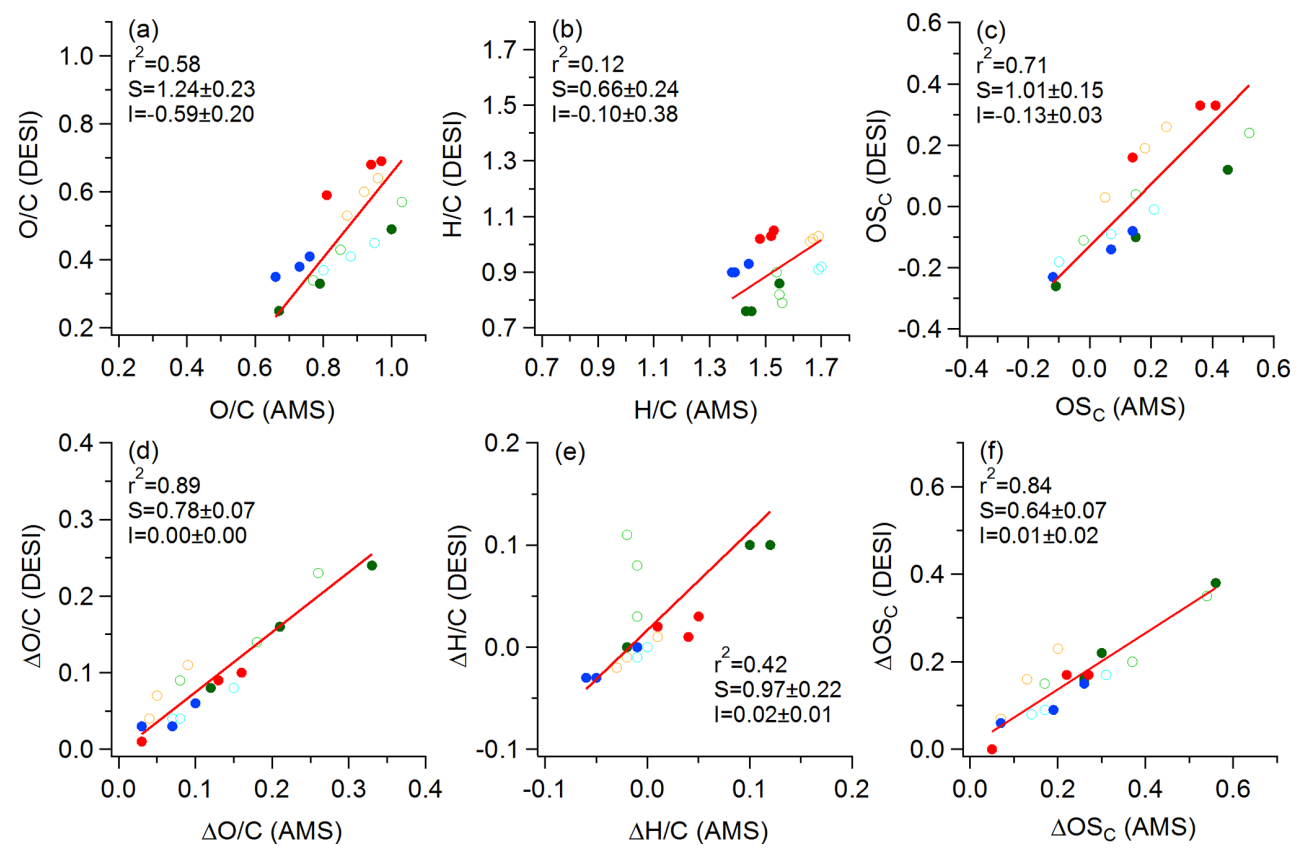

Figure A1. Scatter plots that compare nano-DESI MS and AMS measurements of the average (a) O C, (b) $\mathrm{H} / \mathrm{C}$, and (c) OS $\mathrm{C}$ of aqSOA formed during three different stages of photoreaction and (d) $\Delta \mathrm{O} / \mathrm{C}$, (e) $\Delta \mathrm{H} / \mathrm{C}$, and (f) $\Delta \mathrm{OS}_{\mathrm{C}}$ between different stages. The $\Delta$ denotes the difference between different reaction stages (i.e., P2-P1, P3-P2, P3-P1). All linear regressions were performed using orthogonal distance regression $(\mathrm{ODR})$ and the slopes $(S)$, intercepts $(I)$, and correlation coefficients $\left(r^{2}\right)$ are shown in the legends. Different experimental conditions are represented by the symbols shown in the legend. The $\mathrm{O} / \mathrm{C}, \mathrm{H} / \mathrm{C}$, and $\mathrm{OS}_{\mathrm{C}}$ values shown here are also summarized in Table 1. 


\section{The Supplement related to this article is available online at doi:10.5194/acp-16-4511-2016-supplement.}

Acknowledgements. This work was supported by the US National Science Foundation, grant no. AGS-1036675, and the California Agricultural Experiment Station (projects CA-D-ETX-2102-H and CA-D-LAW-6403-RR). The nano-DESI MS measurements were performed at the W. R. Wiley Environmental Molecular Sciences Laboratory (EMSL), a national scientific user facility located at PNNL, and sponsored by the US DOE BER. PNNL is operated for US DOE by Battelle Memorial Institute under contract no. DEAC06-76RL0 1830. Additional funding was provided by a Jastro-Shields Graduate Research Award and a Donald G. Crosby Fellowship at UC Davis to Lu Yu.

Edited by: Y. Cheng

\section{References}

Aiken, A. C., Decarlo, P. F., Kroll, J. H., Worsnop, D. R., Huffman, J. A., Docherty, K. S., Ulbrich, I. M., Mohr, C., Kimmel, J. R., Sueper, D., Sun, Y., Zhang, Q., Trimborn, A., Northway, M., Ziemann, P. J., Canagaratna, M. R., Onasch, T. B., Alfarra, M. R., Prevot, A. S. H., Dommen, J., Duplissy, J., Metzger, A., Baltensperger, U., and Jimenez, J. L.: O / C and OM / OC ratios of primary, secondary, and ambient organic aerosols with highresolution time-of-flight aerosol mass spectrometry, Environ. Sci. Technol., 42, 4478-4485, doi:10.1021/es703009q, 2008.

Altieri, K. E., Hastings, M. G., Peters, A. J., and Sigman, D. M.: Molecular characterization of water soluble organic nitrogen in marine rainwater by ultra-high resolution electrospray ionization mass spectrometry, Atmos. Chem. Phys., 12, 3557-3571, doi:10.5194/acp-12-3557-2012, 2012.

Anastasio, C., Faust, B. C., and Rao, C. J.: Aromatic carbonyl compounds as aqueous-phase photochemical sources of hydrogen peroxide in acidic sulfate aerosols, fogs, and clouds 1. Non-phenolic methoxybenzaldehydes and methoxyacetophenones with reductants (phenols), Environ. Sci. Technol., 31, 218 232, doi:10.1021/es960359g, 1997.

Andreae, M. O. and Gelencsér, A.: Black carbon or brown carbon? The nature of light-absorbing carbonaceous aerosols, Atmos. Chem. Phys., 6, 3131-3148, doi:10.5194/acp-6-3131-2006, 2006.

Bateman, A. P., Laskin, J., Laskin, A., and Nizkorodov, S. A.: Applications of high-resolution electrospray ionization mass spectrometry to measurements of average oxygen to carbon ratios in secondary organic aerosols, Environ. Sci. Technol., 46, 83158324, doi:10.1021/es3017254, 2012.

Blando, J. D. and Turpin, B. J.: Secondary organic aerosol formation in cloud and fog droplets: A literature evaluation of plausibility, Atmos. Environ., 34, 1623-1632, doi:10.1016/S13522310(99)00392-1, 2000

Chang, J. L. and Thompson, J. E.: Characterization of colored products formed during irradiation of aqueous solutions containing $\mathrm{H}_{2} \mathrm{O}_{2}$ and phenolic compounds, Atmos. Environ., 44, 541-551, doi:10.1016/j.atmosenv.2009.10.042, 2010.
Collett, J. L., Hoag, K. J., Sherman, D. E., Bator, A., and Richards, L. W.: Spatial and temporal variations in san joaquin valley fog chemistry, Atmos. Environ., 33, 129-140, 1999.

Donahue, N. M., Kroll, J. H., Pandis, S. N., and Robinson, A. L.: A two-dimensional volatility basis set - Part 2: Diagnostics of organic-aerosol evolution, Atmos. Chem. Phys., 12, 615-634, doi:10.5194/acp-12-615-2012, 2012.

Ervens, B.: Modeling the processing of aerosol and trace gases in clouds and fogs, Chem. Rev., 115, 4157-4198, doi:10.1021/cr5005887, 2015.

Ervens, B., Turpin, B. J., and Weber, R. J.: Secondary organic aerosol formation in cloud droplets and aqueous particles (aqSOA): a review of laboratory, field and model studies, Atmos. Chem. Phys., 11, 11069-11102, doi:10.5194/acp-1111069-2011, 2011.

Feigenbrugel, V., Le Calvé, S., Mirabel, P., and Louis, F.: Henry's law constant measurements for phenol, o-, m-, and p-cresol as a function of temperature, Atmos. Environ., 38, 5577-5588, doi:10.1016/j.atmosenv.2004.06.025, 2004.

Ge, X. L., Zhang, Q., Sun, Y. L., Ruehl, C. R., and Setyan, A.: Effect of aqueous-phase processing on aerosol chemistry and size distributions in fresno, california, during wintertime, Environ. Chem., 9, 221-235, doi:10.1071/en11168, 2012.

George, K. M., Ruthenburg, T. C., Smith, J., Yu, L., Zhang, Q., Anastasio, C., and Dillner, A. M.: Ft-ir quantification of the carbonyl functional group in aqueous-phase secondary organic aerosol from phenols, Atmos. Environ., 100, 230-237, doi:10.1016/j.atmosenv.2014.11.011, 2015.

Graber, E. R. and Rudich, Y.: Atmospheric HULIS: How humic-like are they? A comprehensive and critical review, Atmos. Chem. Phys., 6, 729-753, doi:10.5194/acp-6-729-2006, 2006.

Hallquist, M., Wenger, J. C., Baltensperger, U., Rudich, Y., Simpson, D., Claeys, M., Dommen, J., Donahue, N. M., George, C., Goldstein, A. H., Hamilton, J. F., Herrmann, H., Hoffmann, T., Iinuma, Y., Jang, M., Jenkin, M. E., Jimenez, J. L., Kiendler-Scharr, A., Maenhaut, W., McFiggans, G., Mentel, Th. F., Monod, A., Prévôt, A. S. H., Seinfeld, J. H., Surratt, J. D., Szmigielski, R., and Wildt, J.: The formation, properties and impact of secondary organic aerosol: current and emerging issues, Atmos. Chem. Phys., 9, 5155-5236, doi:10.5194/acp-9-51552009, 2009.

Hawthorne, S. B., Krieger, M. S., Miller, D. J., and Mathiason, M. B.: Collection and quantitation of methoxylated phenol tracers for atmospheric-pollution from residential wood stoves, Environ. Sci. Technol., 23, 470-475, doi:10.1021/es00181a013, 1989.

Hennigan, C. J., Westervelt, D. M., Riipinen, I., Engelhart, G. J., Lee, T., Collett, J. L., Pandis, S. N., Adams, P. J., and Robinson, A. L.: New particle formation and growth in biomass burning plumes: An important source of cloud condensation nuclei, Geophys. Res. Lett., 39, L09805, doi:10.1029/2012g1050930, 2012.

Herrmann, H.: Kinetics of aqueous phase reactions relevant for atmospheric chemistry, Chem. Rev., 103, 4691-4716, doi:10.1021/cr020658q, 2003.

Jimenez, J. L., Canagaratna, M. R., Donahue, N. M., Prevot, A. S. H., Zhang, Q., Kroll, J. H., DeCarlo, P. F., Allan, J. D., Coe, H., Ng, N. L., Aiken, A. C., Docherty, K. S., Ulbrich, I. M., Grieshop, A. P., Robinson, A. L., Duplissy, J., Smith, J. D., Wilson, K. R., Lanz, V. A., Hueglin, C., Sun, Y. L., Tian, J., Laaksonen, A., Raatikainen, T., Rautiainen, J., Vaattovaara, P., 
Ehn, M., Kulmala, M., Tomlinson, J. M., Collins, D. R., Cubison, M. J., Dunlea, E. J., Huffman, J. A., Onasch, T. B., Alfarra, M. R., Williams, P. I., Bower, K., Kondo, Y., Schneider, J., Drewnick, F., Borrmann, S., Weimer, S., Demerjian, K., Salcedo, D., Cottrell, L., Griffin, R., Takami, A., Miyoshi, T., Hatakeyama, S., Shimono, A., Sun, J. Y., Zhang, Y. M., Dzepina, K., Kimmel, J. R., Sueper, D., Jayne, J. T., Herndon, S. C., Trimborn, A. M., Williams, L. R., Wood, E. C., Middlebrook, A. M., Kolb, C. E., Baltensperger, U., and Worsnop, D. R.: Evolution of organic aerosols in the atmosphere, Science, 326, 1525-1529, doi:10.1126/science.1180353, 2009.

Kroll, J. H. and Seinfeld, J. H.: Chemistry of secondary organic aerosol: Formation and evolution of low-volatility organics in the atmosphere, Atmos. Environ., 42, 3593-3624, doi:10.1016/j.atmosenv.2008.01.003, 2008.

Kroll, J. H., Smith, J. D., Che, D. L., Kessler, S. H., Worsnop, D. R., and Wilson, K. R.: Measurement of fragmentation and functionalization pathways in the heterogeneous oxidation of oxidized organic aerosol, Phys. Chem. Chem. Phys., 11, 8005-8014, doi:10.1039/B905289E, 2009.

Kroll, J. H., Donahue, N. M., Jimenez, J. L., Kessler, S. H., Canagaratna, M. R., Wilson, K. R., Altieri, K. E., Mazzoleni, L. R., Wozniak, A. S., Bluhm, H., Mysak, E. R., Smith, J. D., Kolb, C. E., and Worsnop, D. R.: Carbon oxidation state as a metric for describing the chemistry of atmospheric organic aerosol, Nat. Chem., 3, 133-139, doi:10.1038/nchem.948, 2011.

Laskin, A., Laskin, J., and Nizkorodov, S. A.: Chemistry of atmospheric brown carbon, Chem. Rev., 115, 4335-4382, doi:10.1021/cr5006167, 2015.

Lee, A. K. Y., Hayden, K. L., Herckes, P., Leaitch, W. R., Liggio, J., Macdonald, A. M., and Abbatt, J. P. D.: Characterization of aerosol and cloud water at a mountain site during WACS 2010: secondary organic aerosol formation through oxidative cloud processing, Atmos. Chem. Phys., 12, 7103-7116, doi:10.5194/acp-12-7103-2012, 2012.

Lee, H. J., Aiona, P. K., Laskin, A., Laskin, J., and Nizkorodov, S. A.: Effect of solar radiation on the optical properties and molecular composition of laboratory proxies of atmospheric brown carbon, Environ. Sci. Technol., 48, 10217-10226, doi:10.1021/es502515r, 2014.

Lim, Y. B., Tan, Y., Perri, M. J., Seitzinger, S. P., and Turpin, B. J.: Aqueous chemistry and its role in secondary organic aerosol (SOA) formation, Atmos. Chem. Phys., 10, 1052110539, doi:10.5194/acp-10-10521-2010, 2010.

Morgan, W. T., Allan, J. D., Bower, K. N., Highwood, E. J., Liu, D., McMeeking, G. R., Northway, M. J., Williams, P. I., Krejci, R., and Coe, H.: Airborne measurements of the spatial distribution of aerosol chemical composition across Europe and evolution of the organic fraction, Atmos. Chem. Phys., 10, 4065-4083, doi:10.5194/acp-10-4065-2010, 2010.

Nannoolal, Y., Rarey, J., Ramjugernath, D., and Cordes, W.: Estimation of pure component properties: Part 1. Estimation of the normal boiling point of non-electrolyte organic compounds via group contributions and group interactions, Fluid Phase Equilibr., 226, 45-63, doi:10.1016/j.fluid.2004.09.001, 2004.

Nannoolal, Y., Rarey, J., and Ramjugernath, D.: Estimation of pure component properties: Part 3. Estimation of the vapor pressure of non-electrolyte organic compounds via group contributions and group interactions, Fluid Phase Equilibr., 269, 117-133, doi:10.1016/j.fluid.2008.04.020, 2008.

Ng, N. L., Canagaratna, M. R., Zhang, Q., Jimenez, J. L., Tian, J., Ulbrich, I. M., Kroll, J. H., Docherty, K. S., Chhabra, P. S., Bahreini, R., Murphy, S. M., Seinfeld, J. H., Hildebrandt, L., Donahue, N. M., DeCarlo, P. F., Lanz, V. A., Prévôt, A. S. H., Dinar, E., Rudich, Y., and Worsnop, D. R.: Organic aerosol components observed in Northern Hemispheric datasets from Aerosol Mass Spectrometry, Atmos. Chem. Phys., 10, 46254641, doi:10.5194/acp-10-4625-2010, 2010.

Pankow, J. F. and Barsanti, K. C.: The carbon numberpolarity grid: A means to manage the complexity of the mix of organic compounds when modeling atmospheric organic particulate matter, Atmos. Environ., 43, 2829-2835, doi:10.1016/j.atmosenv.2008.12.050, 2009.

Renard, P., Siekmann, F., Salque, G., Demelas, C., Coulomb, B., Vassalo, L., Ravier, S., Temime-Roussel, B., Voisin, D., and Monod, A.: Aqueous-phase oligomerization of methyl vinyl ketone through photooxidation - Part 1: Aging processes of oligomers, Atmos. Chem. Phys., 15, 21-35, doi:10.5194/acp-1521-2015, 2015.

Roach, P. J., Laskin, J., and Laskin, A.: Molecular characterization of organic aerosols using nanospray-desorption/electrospray ionization-mass spectrometry, Anal. Chem., 82, 7979-7986, doi:10.1021/ac101449p, 2010a.

Roach, P. J., Laskin, J., and Laskin, A.: Nanospray desorption electrospray ionization: An ambient method for liquid-extraction surface sampling in mass spectrometry, Analyst, 135, 2233-2236, doi:10.1039/c0an00312c, 2010b.

Romonosky, D. E., Laskin, A., Laskin, J., and Nizkorodov, S. A.: High-resolution mass spectrometry and molecular characterization of aqueous photochemistry products of common types of secondary organic aerosols, J. Phys. Chem. A, 119, 2594-2606, doi:10.1021/jp509476r, 2015.

Sagebiel, J. C. and Seiber, J. N.: Studies on the occurrence and distribution of wood smoke marker compounds in foggy atmospheres, Environ. Toxicol. Chem., 12, 813-822, doi:10.1002/etc.5620120504, 1993.

Schauer, J. J., Kleeman, M. J., Cass, G. R., and Simoneit, B. R. T.: Measurement of emissions from air pollution sources. 3. $C_{1}-C_{29}$ organic compounds from fireplace combustion of wood, Environ. Sci. Technol., 35, 1716-1728, doi:10.1021/es001331e, 2001.

Smith, J. D., Sio, V., Yu, L., Zhang, Q., and Anastasio, C.: Secondary organic aerosol production from aqueous reactions of atmospheric phenols with an organic triplet excited state, Environ. Sci. Technol., 48, 1049-1057, doi:10.1021/es4045715, 2014.

Smith, J. D., Kinney, H., and Anastasio, C.: Aqueous benzene-diols react with an organic triplet excited state and hydroxyl radical to form secondary organic aerosol, Phys. Chem. Chem. Phys., 17, 10227-10237, doi:10.1039/C4CP06095D, 2015.

Sun, Y., Zhang, Q., Macdonald, A. M., Hayden, K., Li, S. M., Liggio, J., Liu, P. S. K., Anlauf, K. G., Leaitch, W. R., Steffen, A., Cubison, M., Worsnop, D. R., van Donkelaar, A., and Martin, R. V.: Size-resolved aerosol chemistry on Whistler Mountain, Canada with a high-resolution aerosol mass spectrometer during INTEX-B, Atmos. Chem. Phys., 9, 3095-3111, doi:10.5194/acp9-3095-2009, 2009.

Sun, Y. L., Zhang, Q., Anastasio, C., and Sun, J.: Insights into secondary organic aerosol formed via aqueous-phase reactions of 
phenolic compounds based on high resolution mass spectrometry, Atmos. Chem. Phys., 10, 4809-4822, doi:10.5194/acp-104809-2010, 2010.

Yasmeen, F., Vermeylen, R., Szmigielski, R., Iinuma, Y., Böge, O., Herrmann, H., Maenhaut, W., and Claeys, M.: Terpenylic acid and related compounds: precursors for dimers in secondary organic aerosol from the ozonolysis of $\alpha$ - and $\beta$-pinene, Atmos. Chem. Phys., 10, 9383-9392, doi:10.5194/acp-10-9383-2010, 2010.

Yee, L. D., Kautzman, K. E., Loza, C. L., Schilling, K. A., Coggon, M. M., Chhabra, P. S., Chan, M. N., Chan, A. W. H., Hersey, S. P., Crounse, J. D., Wennberg, P. O., Flagan, R. C., and Seinfeld, J. H.: Secondary organic aerosol formation from biomass burning intermediates: phenol and methoxyphenols, Atmos. Chem. Phys., 13, 8019-8043, doi:10.5194/acp-13-8019-2013, 2013.

Yu, L., Smith, J., Laskin, A., Anastasio, C., Laskin, J., and Zhang, Q.: Chemical characterization of SOA formed from aqueousphase reactions of phenols with the triplet excited state of carbonyl and hydroxyl radical, Atmos. Chem. Phys., 14, 1380113816, doi:10.5194/acp-14-13801-2014, 2014.
Zhang, Q. and Anastasio, C.: Conversion of fogwater and aerosol organic nitrogen to ammonium, nitrate, and nox during exposure to simulated sunlight and ozone, Environ. Sci. Technol., 37, 3522-3530, doi:10.1021/es034114x, 2003.

Zhang, Q., Jimenez, J. L., Canagaratna, M. R., Allan, J. D., Coe, H., Ulbrich, I., Alfarra, M. R., Takami, A., Middlebrook, A. M., Sun, Y. L., Dzepina, K., Dunlea, E., Docherty, K., DeCarlo, P. F., Salcedo, D., Onasch, T., Jayne, J. T., Miyoshi, T., Shimono, A., Hatakeyama, S., Takegawa, N., Kondo, Y., Schneider, J., Drewnick, F., Borrmann, S., Weimer, S., Demerjian, K., Williams, P., Bower, K., Bahreini, R., Cottrell, L., Griffin, R. J., Rautiainen, J., Sun, J. Y., Zhang, Y. M., and Worsnop, D. R.: Ubiquity and dominance of oxygenated species in organic aerosols in anthropogenically-influenced northern hemisphere midlatitudes, Geophys. Res. Lett., 34, L13801, doi:10.1029/2007GL029979, 2007. 